FEDERAL RESERVE BANK OF SAN FRANCISCO

WORKING PAPER SERIES

\title{
Capital Account Liberalization: Theory, Evidence, and Speculation
}

\author{
Peter Blair Henry \\ Stanford University, Graduate School of Business, \\ Brookings Institution and NBER
}

November 2006

Working Paper 2007-32

http://www.frbsf.org/publications/economics/papers/2007/wp07-32bk.pdf

The views in this paper are solely the responsibility of the authors and should not be interpreted as reflecting the views of the Federal Reserve Bank of San Francisco or the Board of Governors of the Federal Reserve System. This paper was produced under the auspices of the Center for Pacific Basin Studies within the Economic Research Department of the Federal Reserve Bank of San Francisco. 
NBER WORKING PAPER SERIES

CAPITAL ACCOUNT LIBERALIZATION:

THEORY, EVIDENCE, AND SPECULATION

Peter Blair Henry

Working Paper 12698

http://www.nber.org/papers/w12698

\section{NATIONAL BUREAU OF ECONOMIC RESEARCH \\ 1050 Massachusetts Avenue \\ Cambridge, MA 02138}

November 2006

I gratefully acknowledge financial support from an NSF CAREER Award, the John and Cynthia Fry Gunn Faculty Fellowship, and the Freeman Spogli Institute for International Studies. I thank Anusha Chari, Roger Gordon, Diana Kirk, John McMillan, Paul Romer, and two anonymous referees for helpful comments. Diego Sasson provided excellent research assistance. Finally, I thank Sir K. Dwight Venner and the Research Department of the Eastern Caribbean Central Bank for hosting me in the summer of 1994, when I first started thinking about the issues addressed in the paper.

(C) 2006 by Peter Blair Henry. All rights reserved. Short sections of text, not to exceed two paragraphs, may be quoted without explicit permission provided that full credit, including $\odot$ notice, is given to the source. 
Capital Account Liberalization: Theory, Evidence, and Speculation

Peter Blair Henry

NBER Working Paper No. 12698

November 2006

JEL No. E6,F3,F4,G15,O16

\begin{abstract}
$\underline{\text { ABSTRACT }}$
Writings on the macroeconomic impact of capital account liberalization find few, if any, robust effects of liberalization on real variables. In contrast to the prevailing wisdom, I argue that the textbook theory of liberalization holds up quite well to a critical reading of this literature. The lion's share of papers that find no effect of liberalization on real variables tell us nothing about the empirical validity of the theory, because they do not really test it. This paper explains why it is that most studies do not really address the theory they set out to test. It also discusses what is necessary to test the theory and examines papers that have done so. Studies that actually test the theory show that liberalization has significant effects on the cost of capital, investment, and economic growth.
\end{abstract}

Peter Blair Henry

Stanford University, Graduate School of Business

Stanford, CA 94305-5015

Brookings Institution

and NBER

pbhenry@stanford.edu 


\section{Introduction}

A capital account liberalization is a decision by a country's government to move from a closed capital account regime, where capital may not move freely in and out of the country, to an open capital account system in which capital can enter and leave at will. Broadly speaking, there are two starkly different views about the wisdom of capital account liberalization as a policy choice for developing countries.

The first view, Allocative Efficiency, draws heavily on the predictions of the standard neoclassical growth model pioneered by Solow (1956). In the neoclassical model, liberalizing the capital account facilitates a more efficient international allocation of resources and produces all kinds of salubrious effects. Resources flow from capital-abundant developed countries, where the return to capital is low, to capital-scarce developing countries where the return to capital is high. The flow of resources into the developing countries reduces their cost of capital, triggering a temporary increase in investment and growth that permanently raises their standard of living (Fischer, 1998, 2003; Obstfeld, 1998; Rogoff, 1999; Summers, 2000). Motivated in part by the prospective gains from incorporating Allocative Effciency arguments into their economic policies, dozens of developing-country governments from Santiago to Seoul have implemented some form of capital account liberalization over the past 20 years.

The alternative view regards Allocative Efficiency as a fanciful attempt to extend the results on the gains to international trade in goods to international trade in assets. The predictions of Allocative Efficiency hold only where there are no distortions to the economy other than barriers to free capital flows. Because there are many other distortions in developing countries, skeptics argue that the theoretical predictions of the neoclassical model bear little resemblance to the reality of capital account policy. This alternative view is best characterized 
by an article provocatively titled, "Who Needs Capital Account Convertibility?" (Rodrik, 1998). ${ }^{1}$ Rodrik's empirical analysis finds no correlation between the openness of countries' capital accounts and the amount they invest or the rate at which they grow. He concludes that the benefits of an open capital account, if indeed they exist, are not readily apparent, but that the costs are manifestly evident in the form of recurrent emerging-markets crises.

Since the publication of Rodrik's polemic, evidence has seemed to mount in support of the view that capital account liberalization has no impact on investment, growth, or any other real variable with significant welfare implications. For example, in his survey of the research on capital account liberalization, Eichengreen (2001) concludes that the literature finds, at best, ambiguous evidence that liberalization has any impact on growth. In another review of the literature, Edison, Klein, Ricci, and Sløk (2004) survey ten studies of liberalization and document that only three uncover an unambiguously positive effect of liberalization on growth. Finally, in their comprehensive survey of the research on financial globalization, Prasad, Rogoff, Wei, and Kose (2003) extend the Edison et al. (2004) survey to fourteen studies, but still find only three that document a significant positive relationship between international financial integration and economic growth. Prasad et al. (2003) conclude that “.... an objective reading of the vast research effort to date suggests that there is no strong, robust, and uniform support for the theoretical argument that financial globalization per se delivers a higher rate of economic growth."

In contrast to existing surveys, this article demonstrates that a critical reading of the literature reveals that the textbook theory of liberalization stands up to the data quite well. It is true that most papers find no effect of liberalization on growth. But these papers tell us nothing

\footnotetext{
${ }^{1}$ See also Bhagwati (1998) and Stiglitz (1999, 2000, 2002).
} 
about the empirical validity of the theory. They perform purely cross-sectional regressions that look for a positive correlation between capital account openness and economic growth, implicitly testing whether capital account policy has permanent effects on differences in long-run growth rates across countries. The fundamental problem with this approach is that the neoclassical model provides no theoretical basis for conducting such tests. The model makes no predictions about the correlation between capital account openness and long-run growth rates across countries, and certainly does not suggest the causal link needed to justify cross-sectional regressions.

What the neoclassical model does predict is that liberalizing the capital account of a capital-poor country will temporarily increase the growth rate of its GDP per capita. The temporary increase in growth matters, because it permanently raises the country's standard of living. However, as it is the increase in the level of GDP per capita that is permanent—not its rate of growth - theory dictates that one tests for either a permanent level effect or a temporary growth effect. Testing for a permanent growth effect makes no sense because capital accumulation, which is subject to diminishing returns, is the only channel through which liberalization affects growth in the neoclassical model.

A small but growing branch of the literature takes the time series nature of the neoclassical model's prediction seriously. It does so by investigating whether countries invest more and grow faster in the immediate aftermath of a discrete change in their capital account policy. In contrast to work that looks for a permanent impact of capital account openness on growth across countries, papers in the policy-experiment genre find that opening the capital account within a given country consistently generates economically large and statistically significant effects, not only on economic growth, but also on the cost of capital and investment. 
While the policy-experiment literature removes any serious doubts about whether liberalization has real effects, its findings raise more questions than they resolve. Are the magnitudes of the documented effects plausible? Do the transmission mechanisms emphasized by the theory really drive the results, or are other forces at work? With their focus on aggregate data, papers in the policy-experiment genre do not have enough empirical power to be of any use. Fortunately, a new wave of papers demonstrates how to make progress on these and other important questions by using firm-level data. Analyzing capital account liberalization at the level of the firm instead of the country provides greater clarity about the ways in which liberalization affects the real economy.

Disaggregating the data also brings clarity to the contentious debate on liberalization and crises. Because there are many different ways to liberalize the capital account, when trying to determine whether liberalizations cause crises, it is critical to specify exactly what kind of liberalization you mean. At a minimum, the distinction between debt and equity is critical. Recent research demonstrates that liberalization of debt flows-particularly short-term, dollardenominated debt flows—can cause problems. On the other hand, all the evidence we have indicates that countries derive substantial benefits from opening their equity markets to foreign investors.

The rest of this paper proceeds as follows. Section 2 presents an organizing theoretical framework. Section 3 reviews the literature on the cross-sectional approach to the macroeconomic effects of capital account liberalization. Section 4 uses the framework from Section 2 to explain why the cross-sectional literature finds no real effects of liberalization. Section 5 discusses the policy-experiment approach to the macroeconomic effects of liberalization. Section 6 discusses problems with the policy-experiment approach. Section 7 
reviews recent advances using firm-level data. Section 8 examines whether liberalizations cause crises. Section 9 concludes.

\section{Capital Account Liberalization and the Neoclassical Growth Model}

This section illustrates the fundamental predictions of the neoclassical growth model about the impact of capital account liberalization on a developing country. The framework is not novel, but it brings clarity to the discussion of the empirical literature that follows in Section 3.

Assume that output is produced using capital, labor, and a Cobb-Douglas production function with labor-augmenting technological progress:

$$
Y=F(K, A L)=K^{\alpha}(A L)^{1-\alpha}
$$

Let $k=\frac{K}{A L}$ be the amount of capital per unit of effective labor and $y=\frac{Y}{A L}$ the amount of output per unit of effective labor. Using this notation and the homogeneity of the production function we have:

$$
y=f(k)=k^{\alpha}
$$

Let $s$ denote the fraction of national income that is saved each period and assume that capital depreciates at the rate $\delta$, the labor force grows at the rate $n$, and total factor productivity grows at the rate $g$. Saving each period builds up the national capital stock and helps to make capital more abundant. Depreciation, a growing population, and rising total factor productivity, all work in the other direction making capital less abundant. The following equation summarizes the net effect of all these forces on the evolution of capital per unit of effective labor:

$$
\dot{k}(t)=s f(k(t))-(n+g+\delta) k(t)
$$


When $\dot{k}(t)=0$, the economy is in the steady state depicted by Point A in Figure 1. At Point A, the ratio of capital to effective labor $(k)$ is constant. In contrast, the steady-state level of capital $(K)$ is not constant, but growing at the rate $n+g$. Output per worker $\left(\frac{Y}{L}\right)$ grows at the rate $g$.

Finally, the steady state marginal product of capital equals the interest rate plus the depreciation rate:

$$
f^{\prime}\left(k_{s . s t a t e}\right)=r+\delta
$$

Equation (4) gives a general expression of the equilibrium condition for investment. This equation has important implications for the dynamics of a country's investment and growth in the aftermath of capital account liberalization, because the impact of liberalization works through the cost of capital. Let $r^{*}$ denote the exogenously given world interest rate. The standard assumption in the literature is that $r^{*}$ is less than $r$, because the rest of the world has more capital per unit of effective labor than the developing country. It is also standard to assume that the developing country is small, which means that nothing it does affects world prices.

Under these assumptions, when the developing country liberalizes, capital surges in to exploit the difference between the world interest rate and the country's rate of return to capital. The absence of any frictions in the model means that the country's ratio of capital to effective labor jumps immediately to its post-liberalization, steady-state level. Figure 1 depicts this jump as a rightward shift of the vertical dashed line from $k_{\text {s.state }}$ to $k_{\text {s.state }}^{*}$. In the post-liberalization steady state, the marginal product of capital is equal to the world interest rate plus the rate of depreciation:

$$
f^{\prime}\left(k_{s . s t a t e}^{*}\right)=r^{*}+\delta
$$


The instantaneous jump to a new steady state is an unattractive feature of the model, because it implies that the country installs capital at the speed of light. There are a variety of formal ways to slow down the speed of transition, but taking the time to do so here would lead us astray. $^{2}$

The vital fact about the transition dynamics, which would hold true in any model, is that there must be a period of time during which the capital stock grows faster than it does before or after the transition. To see why the growth rate of the capital stock must increase temporarily, recall that in the pre-liberalization steady state the ratio of capital to effective labor $\left(k_{\text {s.state }}\right)$ is constant, and the stock of capital $(K)$ grows at the rate $n+g$. In the post-liberalization steady state, the ratio of capital to effective labor $\left(k_{s . s t a t e}^{*}\right)$ is also constant and the capital stock once again grows at the rate $n+g$. However, because $k_{\text {s.state }}^{*}>k_{\text {s.state }}$, it follows that at some point during the transition, the growth rate of $K$ must exceed $n+g$.

The temporary increase in the growth rate of capital has implications for economic growth, because the growth rate of output per worker is given by the formula $\gamma_{\frac{Y}{L}}=\alpha \frac{\dot{k}}{k}+g$. Since the growth rate of $K$ exceeds $n+g$ at some point during the transition, $\frac{\dot{k}}{k}$ must be greater than 0 during the corresponding interval of time. Therefore, the growth rate of output per worker also increases temporarily.

Figure 2 illustrates the time paths of the interest rate, the growth rates of capital and output per worker, and the natural log of output per worker during the aftermath of capital account liberalization in the neoclassical growth model. Figures 3 through 5, which display the

\footnotetext{
${ }^{2}$ See for example Chapter 2 of Barro and Sala-i-Martin (1995).
} 
response of the cost of capital, investment, and growth during eighteen real-life capital account liberalization episodes, bear a striking resemblance to Figure 2. Section 6 discusses the details behind the construction of Figures 3 through 5 .

If the evidence lines up with the theory, then why does such a large literature fail to find that liberalization has any real effects? This is the question to which we now turn.

\section{The Cross-Sectional Approach to Measuring the Impact of Liberalization}

Does capital account liberalization promote a more efficient allocation of resources across countries? This section describes the methodology, data, and results associated with the traditional, cross-sectional approach to this question.

Attempts to measure the impact of capital account liberalization on economic performance require information on countries' capital account policies. The IMF's Annual Report on Exchange Arrangements and Exchange Restrictions (AREAER) provides the most readily available, standardized source of such information. Available since 1967, the AREAER provides a list of the rules and regulations governing resident and nonresident capital-account transactions in each country, a table that summarizes the presence of restrictions, and a qualitative judgement on whether the country has an open or closed capital account. For the editions of AREAER published between 1967 and 1996, the summary table contains a single line (line E2) entitled, "Restrictions on payments for capital transactions." The presence of a bullet point in line E2 indicates that the country has some form of restrictions on capital account transactions. In effect, line E2 delivers a binary judgment that takes on the value one if any capital controls are in place and zero otherwise.

The typical study maps the qualitative information from Line E2 into a quantitative 
measure of capital account openness by tallying the number of years that each country was judged to have an open capital account. That tally is then divided by the total number of years in the period to produce a number called SHARE — the fraction of years over a given period that the IMF judged the country to be free from "Restrictions on payments for capital account transactions." For example, if a country had an open capital account for 3 of the 10 years from 1986 to 1995 , then SHARE is equal to 0.3 .

\section{A. Empirical Methodology}

Papers that use the variable SHARE assess the real effects of capital account liberalization by running some variant of the following cross-country growth regression:

$$
\mathrm{GROWTH}_{i}=a+b^{*} \mathrm{SHARE}_{i}+\mathrm{CONTROLS}_{i}+\varepsilon_{i}
$$

where $\mathrm{GROWTH}_{i}$ denotes the average growth rate of real GDP per capita in country $i$ over the time period in question — typically about twenty years — and CONTROLS $S_{i}$ denotes the usual set of control variables used in cross-country growth regressions in the tradition of Barro (1991). With the variable SHARE in hand, estimating equation (6) is a relatively straightforward exercise, because data on the left-hand-side variable are readily available from standard sources such as the International Monetary Fund's (IMF) International Financial Statistics (IFS).

Because equation (6) does not contain time subscripts, it makes no use of the variation in growth rates or openness over time within a given country. In other words, it identifies the impact of capital account policy exclusively through the cross-country variation in average growth rates and fraction of years open. In effect, the estimation procedure tests whether countries with open capital accounts have higher long-run growth rates than countries whose capital accounts are closed. 
Although this test is clearly at odds with the predictions of the neoclassical growth model reviewed in Section 2, a large number of papers use Equation (6), or a close cousin, as their benchmark of analysis. Of the fourteen studies of liberalization and growth summarized in Table 3 of the survey by Prasad, Rogoff, Wei, and Kose (2003), twelve perform cross-sectional regressions. The corresponding numbers from other surveys are nine of ten in Table 6 of Edison, Klein, Ricci, and Sløk (2004); eleven of twelve in Table 1 of Calderon, Loayza, and SchmidtHebbel (2004); and twenty-two of twenty-five in Kose, Prasad, Rogoff, and Wei (2006). Given the prevalence of the cross-sectional regression approach in the literature on the macroeconomic effects of capital account liberalization, it is important to understand what these papers do, the results they find, and how to interpret the evidence.

\section{B. Evidence}

Attempts to quantify the real effects of capital account liberalization using SHARE have not been kind to the Allocative Efficiency view. Most of the published papers in the crosssectional genre find no effect of liberalization on investment or growth. In the most prominent example of such papers, Rodrik (1998) examines the relation between liberalization and growth in a sample of 100 developed and developing countries from 1975 to 1989. Specifically, Rodrik estimates regressions with average growth rates of GDP per capita on the left-hand-side and SHARE on the right-hand-side. His regressions show no significant correlation between growth and SHARE. Since the theoretical channel from liberalization to growth operates through capital accumulation, Rodrik also regresses the average ratio of investment-to-GDP on SHARE and again finds no significant correlation. He concludes that there is no evidence to suggest that countries with fewer restrictions on capital movements grow faster, or invest more, than 
countries with greater restrictions.

One problem with the variable SHARE is that it is constructed from a binary measure of capital controls that treats all countries as either completely closed or completely open. As such, it does not allow for varying degrees of intensity across countries that are classified as open. In an attempt to address this problem, Quinn (1997) uses the information in the AREAER to create a measure of the intensity of capital account openness. Quinn's measure splits capital account transactions into two categories: capital account receipts and capital account payments. For each of the two categories, he assigns a country a score between 0 and 2 , based on a reading of the qualitative description of the AREAER reports. A score of 0 indicates the most restrictive of regimes, where payments for capital transactions are completely forbidden, while a score of 2 indicates that capital transactions are not subject to any taxes or restrictions. Intermediate scores—broken into increments of 0.5-indicate intermediate levels of restrictiveness. Quinn then adds the scores for the two categories to create a variable called CAPITAL, which ranges from 0 to 4. Quinn's indicators are available annually from 1950 to 1997 for 21 OECD countries. For the 43 non-OECD countries in his sample they are available for four different years: 1958, 1973, 1982, and 1988. Quinn runs cross-sectional regressions of average annual growth rates on changes in CAPITAL and finds a positive and significant correlation.

Quinn's data provide a novel attempt at quantifying the intensity of capital account openness, but there are two reasons why they may be of limited use for understanding the impact of capital account liberalization on developing countries. First, Quinn's data for non-OECD countries end in 1988, and therefore do not include the most rapid period of capital account liberalization in the developing world (the late 1980s and early 1990s). Given the time span of his data, Quinn's results may reflect the impact of the move from closed to open capital markets 
among the developed nations. For example, in 197311 OECD countries and 26 developing countries scored 2 or lower on Quinn's index. In 1988 the number of OECD countries with a score of 2 or lower fell to 1 . In contrast, the number of developing countries with a score of 2 or lower rose to 32. Second, Quinn, like Rodrik, also uses a strictly cross-sectional regression framework, so his results imply that easing restrictions on capital account transactions have permanent effects on growth. Since theory predicts only a temporary effect, it is not clear how to interpret this result (more on this in Section 4C).

Whatever the correct interpretation of Quinn's results may be, in finding a positive effect of liberalization on growth, his study is an outlier among the most heavily cited papers that assess the macroeconomic impact of capital account liberalization using cross-sectional regressions. For instance, using data on a sample of developed and developing countries from 1976 to 1995 , Levine and Zervos (1998a) examine whether capital account liberalization has an effect on investment. Like Rodrik and Quinn, they also test for permanent effects, but use a different measure of liberalization. Specifically, Levine and Zervos ask whether countries experience a permanent increase in the growth rate of their capital stocks when their stock markets become more integrated with the rest of the world. They argue that emerging stock markets became more integrated in the 1980s and use 1985 as a common break point across all countries. Next, they examine whether the growth rate of the capital stock of the countries in their sample increased after 1985. They find no evidence that this is the case and conclude that capital account liberalization has no effect on investment.

Among the entire class of papers that test whether countries with more open capital accounts have permanently higher growth rates than those that do not, the bulk of evidence 
supports the findings of Rodrik (1998) and Levine and Zervos (1998a) over Quinn (1997). ${ }^{3}$ For example, of the 10 studies of liberalization surveyed in Edison, Levine, and Sløk (2002), only 3 find an unambiguously positive effect of liberalization on growth (see their Table 6). Prasad, Rogoff, Wei, and Kose (2003) extend the Edison et al. survey to 14 studies, but still find only 3 papers that uncover a significant positive relationship between international financial integration and economic growth.

A number of papers debate whether the absence of significant evidence is a consequence of trying to find an unconditional correlation between openness and long-run growth when the relationship between the two variables is more complicated. Because countries with strong institutions stand to gain more from capital account liberalization, the relationship between growth and capital account policy may be a conditional one that depends on the strength of a country's institutions. ${ }^{4}$ Klein and Olivei (2000) explore this hypothesis using data on 67 countries from 1976 to 1995 . They find a significant correlation between SHARE and growth, but the developed countries in the sample drive the results. There is no significant correlation between growth and SHARE for the non-OECD countries, leading the authors to conclude that capital account liberalization only promotes financial development when done in an environment that is supportive in terms of its overall institutional development.

Edwards (2001) uses Quinn's CAPITAL measure and the variable SHARE to conduct formal tests for a conditional relationship between capital controls and long-run growth rates in a sample of 20 industrial and emerging economies during the 1980s. To test whether the impact of capital account policy varies according to a country's level of development, Edwards interacts each country's capital account openness measure with its level of GDP per capita in 1980. He

\footnotetext{
${ }^{3}$ See also Alesina, Grilli and Milesi-Ferretti (1994), Grilli and Milesi-Ferretti (1995), Kraay (1998), Edison, Levine, and Sløk (2002).

${ }^{4}$ See Kose et al. (2006) for an extensive review of the literature on the conditional effects of liberalization.
} 
finds evidence that an open capital account positively affects growth after a country achieves a certain degree of economic development.

Arteta, Eichengreen and Wyplosz (2001) take exception with Edwards' results on the grounds that he (1) uses Quinn's measure in 1973 and 1988 only; (2) weights observations by GDP per capita in 1985, thereby giving richer countries a higher weight; and (3) uses instruments that may not be appropriate. Using data on 61 countries from 1973 to 1992, Arteta et al. (2001) perform cross-sectional regressions using Ordinary Least Squares (OLS) and Instrumental Variables. They find a fragile association between growth and capital account liberalization and conclude that there is little evidence to suggest that capital account liberalization has a larger impact in high and middle-income countries than in poor developing ones.

Like Arteta et al., Kraay (1998) also finds no evidence of a conditional relationship between capital account liberalization and growth. In fact, while future work may prove otherwise, it seems fair to say that the absence of significant results in the cross-sectional literature is not a consequence of failing to condition their tests on the level of institutional development. ${ }^{5}$ Rather, the next section demonstrates that the ostensible lack of an effect of liberalization on real variables stems from a number of more basic issues common to papers in the cross-sectional literature- -those that test for the conditional and unconditional impact of liberalization on growth alike.

\section{The Reasons Why Cross-Sectional Studies Find No Impact of Liberalization on Growth}

There are at least three reasons why purely cross-sectional regressions find no impact of liberalization on growth (although not all three reasons apply to all papers in this literature).

\footnotetext{
${ }^{5}$ Which is not to deny the importance of institutional considerations.
} 
First, the variable SHARE contains important sources of measurement error that hinder empirical attempts to capture the impact of liberalization on the real economy. Second, many of the papers in this literature include both developed and developing countries in the sample when theory suggests that the two types of countries should be examined separately. ${ }^{6}$ Third, and most importantly, the vast majority of papers in this literature test for a permanent effect of liberalization on growth when the theory says that the impact should only be temporary. I now discuss the empirical consequences of each of these three points in some detail.

\section{A. Measurement Error Problems with Liberalization Indicators}

Cross-sectional studies conclude that capital account liberalization has no real effects because they do not find any correlation between economic growth and broad measures of capital account openness such as SHARE. As discussed in Section 3A, the variable SHARE is constructed using the judgement on capital account openness contained in line E2 of the IMF's AREAER. In turn, the judgement in the AREAER is based on the restrictions applied to an exhaustive list of all possible capital account transactions. ${ }^{7}$ When the IMF changes its assessment of a country's capital account openness, the AREAER provides no information on the specific aspect of the capital account that was liberalized. Because the underlying data provide no indication of what has been liberalized, neither can any index that is based on such data. Without any indication of what drives the variation in SHARE, it is also unclear how to map that variation to a well-articulated model for the purpose of empirical estimation.

For example, AREAER does not tell whether the IMF made a change in the judgement

\footnotetext{
${ }^{6}$ Some of the papers in this literature do acknowledge differences between countries (see the discussion in Section 3C). But papers that do acknowledge the importance of country heterogeneity also use the SHARE variable to test for permanent effects of liberalization.

${ }^{7}$ For an extensive enumeration of these transactions, see the appendix of Kose et al. (2006)
} 
about the openness of a country's capital account because of an easing of restrictions on capital inflows or capital outflows. This distinction matters. Theory predicts that when a capital-poor country liberalizes capital inflows it will experience a permanent fall in its cost of capital and a temporary increase in the growth rate of its capital stock and GDP per capita. In principle, if that same developing country were to liberalize capital outflows nothing would happen to its cost of capital, investment, or GDP.

\section{B. Country Heterogeneity}

The second reason why cross-sectional studies may fail to find significant effects of liberalization is related to the first. Many cross-sectional studies lump both developed and developing countries together in their sample. Including both sets of countries increases sample size, but doing so without employing an empirical methodology that explicitly recognizes the fundamental theoretical difference between developed and developing countries undermines the study's ability to interpret the data. Again, the neoclassical model predicts that capital account liberalization will have a different impact on a developing country than on a developed one. Developing countries are capital poor and should experience net capital inflows, a permanent fall in their cost of capital, and a temporary increase in growth when they remove all restrictions on capital flows. In contrast, capital-rich, developed countries should experience exactly the opposite effects. ${ }^{8}$ For instance, with both developing and developed countries included in their samples, the Rodrik (1998) and Levine and Zervos (1998a) results may suggest that capital account liberalization has no effect on investment and growth, but the results may also reflect the opposing effects of liberalization in the developing and developed-country subsamples.

\footnotetext{
${ }^{8}$ Although the rich country's GDP falls because it exports capital, its GNP will rise, as it receives the income that accrues to that capital. I discuss the Lucas (1990) paradox in Section 5.
} 
Developing and developed countries also implemented the process of capital account liberalization at different times. Developed countries liberalized in the late 1970s and early 1980s (Reisen and Fischer, 1993). Most developing countries did not liberalize until the late 1980s and early 1990s (Mathieson and Rojas-Suárez, 1993). The differences in liberalization dates highlight an additional limitation of the Rodrik paper. Since developing-country liberalizations commenced in the late 1980s and early 1990s, empirical attempts to determine whether liberalization boosted investment and growth should use data that extend into the 1990s. Because Rodrik's data end in 1989, they exclude developing-country economic performance in precisely the period when we would expect to see the effects of liberalization. Therefore, it is not clear that Rodrik's data tell us anything about the impact of capital account liberalization on growth in developing countries. ${ }^{9}$

\section{C. Theory Predicts That Liberalization Will Have a Temporary Impact on Growth}

The third and most important reason why cross-sectional studies fail to find any impact of liberalization on growth is that they test for a permanent effect while theory predicts that the impact will only be temporary. To see the point, recall that Equation (6) makes no use of variation in growth rates or openness over time within a given country. Because Equation (6) identifies the impact of liberalization exclusively through cross-country variation in average growth rates and degrees of openness, the regression implicitly tests whether countries with open capital accounts have higher long-run growth rates than those whose capital accounts are closed.

The problem with this test is that we have already seen (in Section 2) that the neoclassical model does not predict that countries with open capital accounts will have higher long-run

\footnotetext{
${ }^{9}$ Figure 5A of Kose et al. (2006) looks at the data from 1985 to 2004. Like Rodrik, they find no significant relationship between growth and capital account openness. The discussion in Section 4C of this paper explains why.
} 
growth rates than countries whose capital accounts are closed. In the neoclassical model, differences in long-run growth rates across countries are driven exclusively by differences in their growth rates of total factor productivity (TFP). Because there is no channel in the model through which capital account liberalization affects TFP growth, strictly speaking, there is no theoretical basis for estimating equation (6). ${ }^{10}$ In other words, papers that estimate the effects of capital account openness on growth do not provide a test of any causal theory.

What the theory does predict is that capital-poor countries will experience a permanent fall in their cost of capital and a temporary increase in the growth rate of their capital stock and GDP per capita when they liberalize. This is an important point, because testing whether countries with more open capital accounts invest more or grow faster than countries with closed capital accounts is not logically equivalent to testing whether countries that liberalize experience a temporary increase in investment and growth. Moreover, the next subsection demonstrates that there are nontrivial examples in which adopting a purely cross-sectional regression framework will lead to specious conclusions about the data.

\section{D. Numerical Example of the Pitfalls of the Cross-Sectional Regression Approach}

Consider two countries (A and B) that are in steady state and have the same level and growth rate of total factor productivity. Country A has a closed capital account while Country B has no capital account restrictions whatsoever. Assume that both countries are small and that the world interest rate $r^{*}$ is lower than $r$, the domestic interest rate in Country A. Since Country B is open and faces the world interest rate, $r^{*}$, Country B will have a higher ratio of capital to effective labor than country A. Because both countries are in steady state and have identical

\footnotetext{
${ }^{10}$ Foreign direct investment (FDI) is one form of inflow that could bring technology in addition to capital. If FDI brings new technology, it could generate knowledge spillovers that result in TFP growth. I discuss the empirical relevance of this consideration in Section 5D.
} 
growth rates of total factor productivity, they will also have identical growth rates of GDP per capita (although B has a higher level of GDP per capita).

Now consider the path of these two economies over the next twenty years under the following scenario: Country A keeps all of its restrictions on capital in place for the first 10 years, but removes all restrictions on capital inflows and outflows for the second ten years. Country B, on the other hand, makes no change in its capital account policy and remains completely open for the entire 20 -year period.

The transition dynamics in this example follow immediately from the discussion in Section 2. Country B continues to grow at its steady-state rate, because nothing there has changed. In order to understand what happens to Country A when it liberalizes, recognize that as soon as it does so it will face the same cost of capital as Country B. Therefore, when Country A reaches its new steady state, it will have the same ratio of capital to effective labor as Country B. In order for Country A to reach its new, higher, steady-state ratio of capital to effective labor, the growth rate of its capital stock must exceed its growth rate of effective labor throughout the transition to its new equilibrium. Since A began in a steady state where capital and effective labor were growing at the same rate, the growth rate of A's capital stock must increase temporarily.

The temporary increase in the growth rate of A's capital stock will also generate a temporary increase in the growth rate of its GDP per capita. Since GDP per capita in A and B were growing at the same rate before the shock, it follows that A grows faster than B throughout A's transition to its new steady state. Because A grows faster than B throughout the transition, it also follows that A will have a higher average growth rate for the twenty-year period under consideration than Country B. 
What would we conclude about the impact of capital account openness on growth if, using data from multiple countries like like $\mathrm{A}$ and $\mathrm{B}$, we ran a regression of GROWTH on SHARE? The answer is that we would conclude that capital account openness has a negative impact on growth. To see why, remember that A's capital account was open for 10 years and closed for 10 . This means that SHARE for Country A is 0.5 , a smaller number than the value of SHARE for Country B, which is equal to 1 . Since A has faster growth and a lower value of SHARE over the period than Country B, it follows that regressing GROWTH on SHARE would produce a negative coefficient on SHARE, with the attendant (and specious) conclusion that liberalization exerts a negative impact on growth. Yet in this example it is clear that Country A's decision to liberalize capital inflows does lead to a temporary increase in growth. The strictly cross-sectional regression framework is simply powerless to detect the effect.

Again, if the goal is to understand whether capital account liberalization has real effects, then theory tells us that the right question to ask is the following: Do we see a fall in the cost of capital and a temporary increase in investment and growth when developing countries liberalize restrictions on capital inflows? The most direct and transparent way of answering this question is to examine whether the behavior of the cost of capital, investment, and growth in the immediate aftermath of liberalization differs from its behavior in the immediately preceding period. We now discuss a class of papers which attempt to do just that.

\section{The Policy-Experiment Approach to Capital Account Liberalization}

Examining the behavior of real variables before and after the removal of restrictions on capital inflows requires information about the date on which the restrictions were lifted. The policy-experiment approach grapples with the complexity of identifying liberalization dates by 
narrowing the scope of the problem. Instead of trying to determine the date on which the entire capital account was judged to be open, as in the cross-sectional approach, the policy-experiment literature tries to identify the first point in time that a country liberalizes a specific aspect of its capital account policy.

One example of liberalizing a specific aspect of the capital account is a decision by a country's government to permit foreigners to purchase shares of companies listed on the domestic stock market. Liberalizing restrictions on the ownership of domestic shares enables foreign capital to flow into a part of the country's economy from which it was previously prohibited. Just such a policy change occurred repeatedly in the late 1980s and early 1990s, as a number of developing countries opened their stock markets to foreign investors for the first time (Claessens and Rhee, 1994). These stock market liberalizations constitute discrete removals of barriers to capital inflows that bear close resemblance to the thought experiment in Section 2. As the closest empirical analogue to the textbook example, stock market liberalizations provide realworld policy experiments that allow researchers to evaluate the empirical validity of the two competing views of capital account liberalization outlined in the introduction.

Since the stock market is forward-looking, the critical question is when does the market first learn of a credible, impending liberalization? In principle, obtaining this information simply involves identifying the date on which the government declares that foreigners may purchase domestic shares. In practice, the liberalization process is not so transparent. The literature uses official policy decree dates when they are available, but in many cases there is no obvious government declaration or policy decree to which one can refer (see for example Levine and Zervos, 1994). When policy decree dates are not available, papers in this area typically pursue two approaches. 
First, many countries initially permitted foreign ownership through closed-end country funds. Since one presumably needs government permission to establish a fund, the first country fund establishment date serves as a proxy for the official implementation date. The second way of indirectly capturing official implementation dates is to monitor the International Finance Corporation's Investability Index (Claessens and Rhee, 1994). The investability index is the ratio of the market capitalization of stocks that foreigners can legally hold to total market capitalization. As such, a large jump in the investability index provides indirect evidence of an official liberalization. In the end, the policy-experiment literature defines the date of a country's first stock market liberalization as the first month with a verifiable occurrence of any of the following: liberalization by policy decree, establishment of the first country fund, or an increase in the investability index beyond a certain threshold. ${ }^{11}$

An important limitation of the policy-experiment approach is that relatively few developing countries have a stock market, publish reliable stock market data, and also implemented a liberalization. Hence, the number of countries that can feasibly be included under the stock-market-liberalization-based implementation of the policy-experiment approach is much smaller than in purely cross-sectional studies (an issue I discuss further in Section 6A.3).

Table 1 presents a list of 18 developing countries that liberalized their stock markets between 1986 and 1993. The third column of the table indicates that the modal indicator of liberalization for this sample is the establishment of a closed-end country fund. Relative to the broader indicators employed elsewhere in the literature, the establishment of a country fund, in particular, and stock market liberalizations in general may seem like a narrow way to define capital account liberalization. But again, it is precisely the narrowness of stock market

\footnotetext{
${ }^{11}$ See Bekaert and Harvey (2000) and Henry (2000a) for further details on the difficulty of dating stock market liberalizations.
} 
liberalizations that make them more useful than broad indicators of capital account liberalization for testing the implications of the theory. For all of the reasons explained in Section 4A, broad indicators such as the IMF's introduce significant measurement error. Since measurement error reduces the statistical power of any regression, it is important to focus on policy experiments where the true variation in the data is large relative to noise. Stock market liberalizations provide just such experiments, because they constitute a radical shift in the degree of capital account openness (Frankel, 1994).

In addition to identifying episodes of large changes in capital account openness, focusing narrowly on stock market liberalization offers another advantage. In contrast with the unspecified easing of restrictions indicated by movements in the variable SHARE, there is no theoretical ambiguity about the expected impact of lifting restrictions on the flow of capital into the stock market of a developing country. Since stocks are risky, however, using stock market liberalizations to examine the impact of capital account liberalization on economic performance raises issues of uncertainty not addressed by the deterministic framework of Section 2 .

\section{A. Extending the Theoretical Framework to Incorporate Uncertainty}

This subsection shows that the fundamental predictions of the deterministic neoclassical model of capital account liberalization extend to the risky-asset setting of the policy-experiment approach. ${ }^{12}$ In the absence of uncertainty, it is optimal to invest until the marginal product of capital equals the interest rate. When the payoff from investing in capital is risky, the interest rate is no longer the relevant hurdle rate for investment. Optimality in a risky world requires that investment take place until the expected marginal product of capital equals the interest rate plus a risk premium to compensate for the uncertain return to capital.

\footnotetext{
${ }^{12}$ The discussion in this section borrows heavily from Bulow and Summers (1984) and Stulz (1999b).
} 
For a country that has not yet opened its stock market to the rest of the world, this means that the first-order condition for investment is: $f^{\prime}(k)^{e}=r+\theta+\delta$, where $f^{\prime}(k)^{e}$ denotes the expected marginal product of capital, $r$ is the domestic interest rate, $\theta$ is the aggregate equity premium, and $\delta$ is the rate of depreciation of the capital stock. In the context of the capital asset pricing model (CAPM), $\theta$ is equal to the price of risk, $\gamma$, times the variance of the market return, so that the first-order condition for investment under uncertainty is:

$$
f^{\prime}(k)^{e}=r+\gamma \operatorname{Var}\left(\tilde{r}_{M}\right)+\delta
$$

Where $\tilde{r}_{M}$ is the risky return to investing in the market.

Starting from the equilibrium in Equation (7), the issue is whether liberalization reduces the cost of capital as it does in Section $2 .{ }^{13}$ The first component of the cost of capital is the domestic interest rate $(r)$ which responds the same way to liberalization as in the case of perfect certainty; it falls to the world interest rate $\left(r^{*}\right)$. The second component of the cost of capital is the aggregate equity premium. Whereas the equity premium before liberalization is equal to the price of risk times the variance of the local market return, the equity premium after liberalization is equal to the price of risk times the covariance of the local market with the rest of the world (see Stulz, 1999b).

The change in both components of the cost of capital means that following liberalization the first-order condition for investment becomes:

$$
f^{\prime}(k)^{e}=r^{*}+\gamma \operatorname{Cov}\left(\tilde{r}_{M}, \tilde{r}_{W}\right)+\delta
$$

Because the world interest rate $\left(r^{*}\right)$ is less than the domestic interest rate $(r)$, comparing the right-hand-side of Equation (8) with that of (7) indicates that liberalization will reduce the cost of

\footnotetext{
${ }^{13}$ For expositional convenience, I assume that liberalization has no effect on the marginal product of capital. Section 4D discusses what happens when this assumption does not hold.
} 
capital if the variance of the domestic market return is greater than its covariance with the world market. Historical stock returns show that this condition holds for emerging stock markets (Stulz, 1999b). Therefore, stock market liberalization reduces the cost of capital, and the attendant predictions about investment and growth follow accordingly.

\section{B. Evidence: The Cost of Capital, Investment, and Growth}

We do not observe the cost of capital directly, but we do observe stock prices. Because stock prices and the cost of capital move inversely, we should observe a one-time revaluation of the stock market if liberalization reduces the cost of capital. In a sample of 12 emerging economies that liberalized between 1986 and 1991, the average country experienced a revaluation of 26 percent in real dollar terms (Henry, 2000a). Kim and Singal (2000) and Martell and Stulz (2003) also document a sharp rise in stock prices in conjunction with liberalizations. ${ }^{14}$ Consistent with these revaluations, liberalizations also coincide with an average fall in dividend yields of 5 to 75 basis points (Bekaert and Harvey, 2000). ${ }^{15}$ While the magnitude of the effect differs slightly depending on the sample of countries and the exact liberalization dates applied, there is broad agreement across all policy-experiment studies that liberalization reduces the cost of capital.

Since liberalizations reduce the cost of capital, some projects that were negative net present value (NPV) before liberalization become worthwhile to undertake once the government permits foreigners to hold domestic shares. Consequently, the rate of capital accumulation should rise until the marginal product of capital is driven down to the country's new, lower cost of capital. If investment increases temporarily, so too should the growth rate of GDP per

\footnotetext{
${ }^{14}$ A related but different literature shows that firms in emerging markets experience stock price increases when they list their shares on stock exchanges in developed countries (see Karolyi, 1998 and Foerster and Karolyi, 1999).

${ }^{15}$ See also Errunza and Miller (2000).
} 
capita. $^{16}$

The policy-experiment approach tests the investment and growth predictions by estimating panel regressions of the following form:

$$
G R O W T H_{i t}=a_{0}+a_{1}^{*} \operatorname{LIBERALIZE}_{i t}+\varepsilon_{i t}
$$

The variable GROWTH generically denotes the growth rate of the variable of interest: the capital stock in the case of the investment regressions and GDP per capita. The variable LIBERALIZE is a country-specific dummy variable that takes on the value one in the year that country $i$ liberalizes (Year [0]) and each of the subsequent five years (Year [+1] through Year [+5]).

Equation (9) highlights two important dimensions along which the policy-experiment approach differs from the traditional cross-sectional regression approach typified by equation (6). First, equation (9) uses every annual observation of each country's growth rate to exploit the variation in growth rates within countries over time. In contrast, equation (6) uses a single number on the left-hand-side — the average growth rate over the time period in question.

Second, the definition of the variable LIBERALIZE ensures that Equation (9) tests for a temporary effect of liberalization on growth instead of a permanent one as in equation (6). If liberalization causes a temporary increase in growth, then estimating Equation (9) should produce a positive and significant estimate of the coefficient on the variable LIBERALIZE. In other words, the coefficient on LIBERALIZE measures the temporary abnormal growth associated with liberalization episodes.

The behavior of both investment and GDP in the aftermath of liberalizations supports the predictions of the neoclassical model. For the 18 countries in Table 1, the raw growth rate of the capital stock rises from an average of 5.4 percent per year in the five years preceding

\footnotetext{
${ }^{16}$ Gourinchas and Jeanne (2006) argue that the welfare implications of the growth effect are de minimus.
} 
liberalization to an average of 6.5 percent in the five-year post-liberalization period (Henry, 2003). Similarly, in a sample of 11 emerging economies, stock market liberalization leads to a 22 percentage point increase in the growth rate of real private investment (Henry, 2000b). Of the eleven countries in the sample, only two do not experience abnormally high rates of investment in the first year after liberalization, and only one in the second year after liberalization. Bekaert, Harvey, and Lundblad (2005) find that the growth rate of GDP per capita increases by a percentage point per annum. An important question that I defer until Section $6 \mathrm{C}$ is whether the growth and investment numbers are mutually consistent.

Figures 3 through 5 summarize the principal findings of the policy-experiment literature by plotting the cost of capital, investment, and growth in event time for the 18 countries listed in Table $1 .{ }^{17}$ When developing countries liberalize capital flows into their stock markets, the cost of capital falls and investment increases along with the growth rate of GDP per capita. In contrast to the cross-sectional studies reviewed in Section 3, the evidence from the policyexperiment approach demonstrates that the real-world impact of capital account liberalization is quite consistent with the Allocative Efficiency view.

\section{C. Economic Reforms}

The policy-experiment evidence is also consistent with interpretations in which liberalization plays no causal role. Figure 3, which uses the dividend yield as a proxy for the cost of capital, helps to demonstrate the point. The theoretical justification for interpreting a fall in the dividend yield as a reduction in the cost of capital comes from Gordon (1962). In the Gordon model, the dividend yield equals the cost of capital, $\rho$, minus the (constant) expected

\footnotetext{
${ }^{17}$ The data used to construct Figure 4, the average growth rate of the real capital stock for the 18 countries in listed in Table 1, comes from Bosworth and Collins (2003).
} 
future growth rate of dividends: $D / P=\rho-g^{e} \cdot{ }^{18}$ If the growth rate of dividends does not change with liberalization, then a fall in the dividend yield implies a fall in the cost of capital. Because liberalizations are part of a general process that involves substantial macroeconomic reforms, however, there is a strong possibility that large changes in expected future growth rates do occur at the same time that countries liberalize.

Columns 4 through 7 of Table 1 demonstrate that the timing of economic reformsinflation stabilization, trade liberalization, and privatization-poses a significant challenge to the central policy-experiment findings reviewed in Section 5B. Stabilizing inflation drives up asset prices, investment, and growth (Bruno and Easterly, 1998; Calvo and Végh, 1998; Easterly, 1996; Fischer, Sahay, and Végh, 2002; Henry, 2000b, 2002). When a country liberalizes trade, domestic production shifts toward the country's comparative advantage, thereby increasing its output for a given stock of capital and labor. Accordingly, trade liberalization is good for growth (Krueger, 1997, 1998; Sachs and Warner, 1995; Frankel and Romer, 1999, Wacziarg and Welch, 2003). Privatization raises the efficiency and value of formerly state-owned enterprises (Megginson, 2001). Finally, in return for adopting reforms, many countries received debt relief under the Brady Plan. Debt relief also has a positive impact on stock prices, investment, and growth in certain emerging economies (Arslanalp and Henry, 2005, 2006a, b).

Papers in the policy-experiment literature approach adopt different methods of trying to disentangle the impact of liberalization from that of other economic reforms. Some papers treat reforms and liberalization symmetrically, constructing dummy variables that take on the value one in the year a reform program of a particular type begins and each of the five subsequent

\footnotetext{
${ }^{18}$ Recall that $\rho=r+\gamma \operatorname{Var}\left(\tilde{r}_{M}\right)$ before liberalization and $\rho=r^{*}+\gamma \operatorname{COV}\left(\tilde{r}_{M}, \tilde{r}_{W}\right)$ after liberalization.
} 
years. ${ }^{19}$ Using the variable "REFORMS" as a convenient shorthand to denote the reform dummies, the key regression then simply becomes an extension of equation (9):

$$
\text { GROWTH }_{i t}=a_{0}+a_{1} * \text { LIBERALIZE }_{i t}+a_{2} * \text { REFORMS } S_{i t}+\varepsilon_{i t}
$$

Other papers, instead of conducting a before-and-after analysis of reforms, use continuous proxies such as the level of inflation and trade openness. ${ }^{20}$ Kose et al. (2006) discuss the relative merits of both approaches on page 19 of their survey.

\section{D. Policy Endogeneity}

The impact of stock market liberalization on stock prices, dividend yields, investment and growth remains statistically and economically significant, after controlling for reforms (Bekaert and Harvey, 2000; Bekaert and Harvey, and Lundblad, 2005; Henry 2000a, b). But an even more difficult interpretation problem remains. Do liberalizations drive up stock prices, investment, and economic growth or does causation run the other way round? Because liberalizing the stock market during bad times may draw criticism for selling off the country at fire sale prices, politicians may be may be more inclined to open up when times are good (Summers, 1994). To the extent that the economy's current and expected future performance influence policy makers' decision to liberalize, the endogeneity problem is quite real.

In trying to think of a legitimate instrument for this problem, one is struck by the distinct lack of variables that are correlated with the decision to liberalize but uncorrelated with the stock market or macroeconomic fundamentals. Changes of political regime are a natural candidate, but in addition to being correlated with liberalizations, political changes also bring new economic programs that influence market expectations. Because none of the papers in the

\footnotetext{
${ }^{19}$ See for example Henry (2000a)

${ }^{20}$ See for instance, Bekaert and Harvey (2000), Bekaert, Harvey, and Lundblad (2005).
} 
policy-experiment literature are fully able to dispel with concerns about endogeneity, the economically large and statistically significant correlations between liberalization and real variables uncovered by the policy-experiment literature require a measured interpretation.

\section{Problems with the Policy-Experiment Approach}

The strength of the policy-experiment approach is that it provides a clear picture of what happens to developing countries when they liberalize capital inflows. The weakness of the policy-experiment approach is that it raises more questions than it answers (even putting aside the issue of endogeneity raised at the end of Section 5). This section of the paper addresses three of those questions.

\section{A. Why Is the Financial Impact of Liberalization So Small?}

Liberalization drives up the value of the stock market by roughly 30 percent in real dollar terms. This is a large number relative to most event studies conducted using US data (see McKinlay, 1997). But it is small in comparison with theoretical predictions about the impact of capital account liberalization. Casual observation suggests that developing countries have much lower ratios of capital to labor than rich countries. If the neoclassical model provides a reasonable description of the world, then we should observe a much larger financial impact when developing countries permit capital flows into their stock markets (Stulz, 1999a, c, 2005).

There are at least three possible explanations for the relatively modest increase in stock prices (decrease in the cost of capital) associated with liberalizations. The first is that the policyexperiment approach treats liberalization as a one-shot event when it is really an incremental process. The second explanation is that the rate of return to capital in developing countries may 
not really be that much higher than in the developed world (Lucas, 1990; Mankiw, 1995). The third is that developing countries do have substantially higher rates of return, but the presence of capital market imperfections causes much of the return differential to persist, even in the face of free capital flows. The next three subsections elaborate on each of these points in turn.

\section{A.1 Treating Liberalization as a Binary Process May Understate Its True Impact}

The policy-experiment literature estimates the change in the cost of capital that occurs the first time a country opens its stock market to foreign investors. The problem with this approach is that countries seldom move from having a completely closed stock market to one that is fully open. Most countries undergo several stock market liberalizations subsequent to the first. South Korea provides a good example. South Korea began allowing foreigners very limited access to its stock market through closed-end country funds as early as 1982, but did not start lifting its statutory ceiling on foreign investment until $1992^{21}$ Even then, Korea did not finish lifting its regulatory ceiling until 1998 (Shin and Park, 2006).

If a country takes several episodes to open its stock market completely, then looking exclusively at the stock market response to its initial opening may understate the total financial impact of the liberalization process (Stulz, 1999b). One way of addressing the issue is to estimate the market response to every opening, sum up all of the responses, and use the resulting number as a proxy for the total liberalization effect. It turns out that stock market responses to liberalizations subsequent to the first are fairly small, so the incremental-opening hypothesis cannot account for the small financial impact of liberalization.

Another alternative is to estimate the total financial impact using continuous measures of

21 See Park and Van Agtmael (1993), Price (1994); and Wilson (1992). 
liberalization such as the IFC's investable index (Edison and Warnock, 2003). Again, the investable index indicates the fraction of the domestic stock market capitalization that foreign investors may legally own. In contrast to the policy-experiment approach, which estimates the one-time response of the stock market at the time of a large, discrete change in the investable index, the continuous approach regresses returns or dividend yields on the level of the investability index over the entire sample. The continuous approach also reveals a small change in the cost of capital. The estimated cumulative fall in the dividend yield is about 140 basis points (De Jong and De Roon, 2005). All in all, the evidence suggests that the dichotomy between the binary measure of liberalization used by policy-experiment papers and the more gradual nature of the process cannot explain the relatively small financial impact of liberalizations.

\section{A.2 Poor Institutions in Developing Countries May Reduce the Return to Capital}

Large differences in capital-to-labor ratios across countries imply large differences in rates of return to capital only if all countries have the same level of total factor productivity. In standard production theory, the level of total factor productivity is captured by the parameter $A$, which is usually taken to be an index of technology or ideas. But it is important to remember that, for a given stock of technology, total factor productivity measures the general efficiency with which an economy transforms capital and labor into output (Solow, 2001). Holding technology constant, there are many factors that may influence this general level of efficiency.

For instance, weak institutions and inappropriate government regulation can distort economic decision making, reduce total factor productivity, and lead to lower rates of return than would otherwise prevail (Harberger, 1998). The rate of return to capital in emerging economies 
may not be much higher than in rich countries if emerging-market governments fail to create "an environment that supports productive activities and encourages capital accumulation, skill acquisition, invention and technology transfer" (Hall and Jones, 1999).

To illustrate the point, Table 2 demonstrates the gap between the G-7 countries and the 18 emerging economies that liberalized their stock markets using some frequently employed measures of the quality of economic institutions. Column 2 shows that according to the Hall and Jones (1999) measure of social infrastructure, the median G-7 country ranks fourteenth of 130 countries, while the median emerging economy ranks sixty-fourth. Columns 3 through 5, which present analogous measures using the Heritage House's Index of Economic Freedom, the World Bank's Ease of Doing Business Index, and the World Economic Forum's Global Competitiveness Index, display a similar pattern.

In other words, the relatively small financial effects of liberalization may simply indicate that the return to capital in developing countries is not that much higher than in the developed world. Recent work using various development accounting methods produces indirect estimates of rates of return that support this view (see, for example, Caselli, 2005, and Caselli and Feyrer, 2006). However, there are few studies that attempt to measure the rate of return to capital in developing countries directly. In my view, this continues to be an important gap in the literature.

\section{A.3 Capital Market Imperfections}

A third explanation for the relatively small financial impact of liberalization is that developing countries really do have higher rates of return to capital, but the presence of capital market imperfections such as agency problems, asymmetric information and poor investor protection leads to a persistent return differential between rich and poor countries (Stulz, 2005). 
Investor protection matters. Where accounting standards and enforcement bodies do not exist to restrain insiders, resources invested in a company may be wasted on superfluous managerial perks or even stolen outright (Jensen, 1986). The insiders may be controlling shareholders, such as a founding family, a firm's top managers, or both. Because outside investors know less than insiders about the firm's prospects and the behavior of its managers, they will demand higher returns or simply not invest.

Strong investor protection can help to mitigate problems of agency and asymmetric information by providing minority shareholders with mechanisms to restrain insiders. A large body of research demonstrates that the degree to which a country's laws protect the legal rights of minority shareholders exerts a significant influence on the size and robustness of capital markets (La Porta, Lopez-de-Silanes, Shleifer, and Vishny 1997, 1998, 2002). Firms located in countries with strong investor protection have greater access to external finance, invest more, and have higher valuations than their counterparts in countries with weak investor protection (LaPorta et al., 1997, 1998, 2002; Shleifer and Vishny, 1997; Rajan, 2000). ${ }^{22}$

Conversely, investors will stay away from countries in which investor protection is weak (Dornbusch, 2000). Table 3 shows the 18 emerging economies that liberalized their stock markets rank lower than developed countries on every commonly used measure of investor protection: the rule of law, efficiency of the judicial system, contract repudiation, expropriation risk, and the accounting system. Weak investor protection decreases effective returns, thereby reducing the incentive for capital to flow from rich to poor countries (Shleifer and Wolfenzon, 2002). ${ }^{23}$ Because minority shareholders in emerging economies receive less protection than their counterparts in rich countries, lifting restrictions on capital inflows may generate smaller

\footnotetext{
${ }^{22}$ In a related paper, Johnson, Boone, Breach, and Friedman (2000) show that measures of investor protection do a better job of explaining stock market declines during the Asian Crisis than do standard macro variables.

${ }^{23}$ See also the discussion in Himmelberg, Hubbard, and Love (2002).
} 
changes in asset prices and capital flows than would occur if emerging economies gave minority shareholders the same average level of protection they receive in developed economies.

Although Table 3 corroborates the basic story, an important question for future research is the extent to which the capital market imperfections view truly explains the relatively small financial impact of liberalization. For instance, an empirical prediction of the market imperfections view is that the impact of liberalization should be larger in countries that have stronger investor protection. Unfortunately, the policy-experiment approach is not well-suited to test this prediction. With typically no more than 25 countries that meet the criteria for sample inclusion, there are simply not enough data points to conduct precise tests of the cross-sectional prediction that liberalization will have a larger impact in countries with stronger investor protection. ${ }^{24}$

In a related exercise that is not a study of liberalization per se, Alfaro, Kalemli-Ozcan, and Volosovych (2006) try to determine whether the capital-market-imperfections view or the weak-institutions view has greater empirical relevance for the observed pattern of asset prices and capital flows to emerging economies. They construct a measure of the strength of institutions for a large cross-section of countries, using variables from Political Risk Service's International Country Risk Guide. As a proxy for international capital market imperfections they construct a measure of economic "remoteness" which they interpret as capturing informational frictions as in Coval and Moskowitz (1999, 2001) and Portes and Rey (2005).

In running horse races between the two views, Alfaro et al. (2006) find that their measure of institutions explains over half of the variation in foreign direct investment and portfolio flows as a fraction of GDP. They interpret their finding as indicative of the primacy of weak

\footnotetext{
${ }^{24}$ Chinn and Ito (2002) do find that countries whose financial systems have a higher level of legal and institutional development benefit more from capital account openness, but like other purely cross-sectional studies, the paper examines the correlation between openness and real variables, not the impact of liberalization per se.
} 
institutions over capital market imperfections for explaining the paucity of capital flows to developing countries. One problem with their interpretation is that it is not clear that economic remoteness is the right proxy for capital market imperfections such as agency problems and investor protection. Furthermore, it is also difficult to say where institutional quality ends and capital market imperfections begin. Poor institutions (e.g., the absence of property rights) lead to market imperfections such as weak investor protection. While it is not clear that one can successfully distinguish between the institutions view and the capital market imperfections view using aggregate cross-country data, the Alfaro et al. (2006) paper does provide empirical support for the notion that the myriad of potential distortions not explicitly modeled in the neoclassical framework can account for some of the Lucas (1990) paradox.

\section{B. Can We Believe the Investment Results?}

Although the financial impact of stock market liberalization is small relative to predictions, the evidence in Section 5B demonstrates that it is apparently still large enough to have significant effects on real investment. However, it is not clear how much confidence we should place in results that attribute economy-wide investment booms to a policy change that affects directly only those firms that are traded on the stock market. In most emerging economies, the economic activity of stock-market-listed firms accounts for a relatively small fraction of GDP, so it is natural to ask whether the aggregate investment booms that occur in the aftermath of liberalizations may be plausibly linked with events that partially open a single component of the capital account.

For instance, the establishment of a country fund is the modal means through which the policy-experiment approach identifies capital account liberalization dates. The size of a country 
fund is typically small relative to the size of the liberalizing country's capital stock. The Chilean liberalization listed in Table 1 illustrates the point. Chile liberalized its stock market in May of 1987, and the vehicle through which it did so was the Toronto Trust Mutual Fund, a Canadian closed-end fund with a net asset value of 37.7 million US dollars. A capital inflow of this size is simply not large enough to account for the size of Chile's subsequent investment boom. Because the capital stock of publicly traded Chilean firms is a subset of the entire economy's, to illustrate the point it is sufficient to show that 37.7 million dollars is small relative to the increase in the capital stock of the publicly traded firms. In 1987 Chile's stock market capitalization was 5.34 billion US dollars, and the ratio of the market value of assets to book value was 0.7. This means that the book value of assets was roughly 7.63 billion US dollars at the time Chile liberalized. In the five years after liberalization, Chile experienced abnormal capital stock growth of 2.2 percentage points per year. Applying this growth number to the capital stock in a continuously compounded fashion for the next five years adds an additional 890 million dollars of productive assets to the economy. The 37.7 million dollar capital inflow can account for less than five percent of this increase.

The apparent incongruity of these numbers forces harder thinking about the validity of the empirical link between liberalization and real investment. In doing so, an important point to keep in mind is that the policy-experiment approach uses country-fund openings as observable de facto indicators of harder-to-pinpoint de jure policy changes. ${ }^{25}$ If country-fund dates are valid proxies for the occurrence of broader, undocumented liberalizations, then significant quantities of capital may flow in through stock markets that are not part of any particular country fund. If that is the case, then the size of the initial country fund will understate the quantity of resources that stock market liberalizations make available to finance an increase in the domestic capital

\footnotetext{
${ }^{25}$ See Kose et al. (2006) for a detailed discussion of de facto versus de jure indicators.
} 
stock. Three facts suggest that closed-end country fund dates do indeed provide nonspecious indicators of a larger move towards open capital markets.

First, a steady stream of country funds and issuances of American Depository Receipts typically follow stock market liberalizations (Karolyi, 2004, Levine and Schmukler, 2005). In the case of Chile, 6 additional country funds with a cumulative net asset value of 991.8 million dollars were established between 1987 and 1992. More generally, Table 4 shows that aggregate net equity inflows to emerging equity markets rise sharply following the median date of countryfund openings.

Second, with the sole exception of Malaysia during the Asian Crisis of 1997-98, none of the stock market liberalization dates from Table 1 were followed by a reversal of freedom of foreign access. ${ }^{26}$ Together with the first fact, this second fact confirms that stock market liberalizations indicate a discrete change in capital account policy that signifies the beginning of a steady march toward greater freedom of capital inflows.

Third, stock market liberalizations coincide with a significant increase in the importation of capital goods. In a sample of 25 countries that liberalized their stock markets between 1980 and 1997, liberalization leads to a 6-percent increase in capital goods as a fraction of total imports, and the share of total machine imports to GDP rises by 12 percent (Alfaro and Hammel, 2006). Because developing countries do not produce a significant portion of the capital goods they use, the observation that imports of capital goods rise in concert with the advent of portfolio equity inflows increases confidence in earlier work on liberalization and aggregate investment.

\section{C. Are the Growth Effects Plausible?}

Stock market liberalizations may be able to account for a nontrivial fraction of country-

\footnotetext{
${ }^{26}$ See Abdelal and Alfaro $(2002,2003)$ for a detailed discussion of the Malaysian case.
} 
wide investment booms, but the increase in the capital stock following liberalizations is too small to account for the observed increase in growth. Bekaert, Harvey, and Lundblad (2005) find that the increase in economic growth due to liberalization is about one percent per year after controlling for a number of variables. This estimate is implausibly large. ${ }^{27}$ To see why, recall that the growth rate of capital increases by about one percent per year following stock market liberalizations and that the elasticity of output with respect to capital is roughly one-third. Therefore, a percentage-point increase in the growth rate of the capital stock cannot raise the growth rate of GDP per capita by much more than one-third of a percentage point.

Within the standard neoclassical framework, any increase in the growth rate of output not due to an increase in the growth rate of capital and labor must be the result of an increase in the growth rate of total factor productivity (TFP). The growth rate of TFP did rise from an average of 0.19 percent per year in the five years preceding stock market liberalization to an average of 1.82 percent per year in the subsequent five years. But one cannot glibly attribute the increase in TFP growth to stock market liberalization. The reason is that the operative channel from liberalization to growth in the neoclassical model runs through capital accumulation. Total factor productivity does not enter into the story, unless stock market liberalizations are associated with a major easing of restrictions on foreign direct investment (FDI).

When foreign firms undertake FDI in the form of green field investments or the purchase of a majority stake of a domestic firm, they may bring new technology and management techniques that increase the efficiency of the acquired firm and generate economy-wide knowledge spillovers. Mexico is the only country in Table 1 whose liberalization date (May 1989) also coincides with a major easing of restrictions on FDI. There was a significant increase

\footnotetext{
${ }^{27}$ See the discussion on page 19 and page 22 of Kose et al. (2006).
} 
in the TFP growth of Mexican plants that changed from domestic to majority foreign ownership (Perez Gonzales, 2005). FDI in Venezuela also increased TFP growth at the plant level (Aitken and Harrison, 1999). ${ }^{28}$ There is no evidence, however, that plant-level productivity gains generate economy-wide knowledge spillovers that stimulate higher aggregate TFP growth (Haddad and Harrison, 1993; Aitken and Harrison, 1999; Gorg and Greenaway, 2004).

Now, capital account liberalization could raise TFP growth if it increased the allocative efficiency of domestic investment, but it is not obvious why it should. It is precisely because economists do not think that capital account liberalization necessarily enhances the efficiency of the domestic financial system, that so many of them recommend enhancing the efficiency of the domestic financial system before opening up to free capital flows (see, for example, Dornbusch, 1983; Edwards, 1984; McKinnon, 1991; Mishkin, 2005).

It is true that capital account liberalization within a country does tend to increase its financial development (Levine, 2001; Levine and Zervos, 1998a, b). It is also true that countries at high levels of financial development allocate capital more efficiently than countries at low levels of financial development (Love, 2003; Wurgler, 2000; Rajan and Zingales, 1998;

Eichengreen, 2004). The temptation, of course, is to invoke transitivity and conclude that capital account liberalization increases domestic allocative efficiency. The problem with such logic is that documenting a positive correlation between the efficiency of capital allocation and financial development in a cross section of countries does not permit us to infer that more financial development within a given country will improve its allocative efficiency. Without a convincing body of time series evidence that the quality of a country's capital allocation improves as its level of financial development rises, no basis exists for concluding that liberalization indirectly

\footnotetext{
${ }^{28}$ For an analysis of the anticipated productivity gains from foreign direct investment using stock market data, see Chari, Ouimet, and Tesar (2004).
} 
improves the efficiency of domestic capital allocation through its impact on financial development. $^{29}$

I am not arguing that one cannot tell stories in which capital account liberalization increases higher TFP growth. Liberalization may ease liquidity constraints (Gupta and Yuan, 2005; Mitton, 2006), thereby enabling firms to adopt technologies that they could not finance prior to the liberalization. Liberalization also facilitates increased risk sharing, which might encourage investment in riskier, higher growth technologies in the spirit of Obstfeld (1994), Levine (1997), or King and Levine (1993). The point is that while the developing countries in this sample may have increased their rate of adoption of new production technologies during the late 1980s and early 1990s, there is simply no intellectually sound way to draw such a conclusion from aggregate data.

In contrast, the aggregate TFP growth numbers are completely consistent with the readily observable evidence on economic reforms. As discussed in Section 6A.2, economic reforms that raise the efficiency of a given stock of capital and labor will increase TFP, and again, Table 1 shows that stock market liberalizations typically coincide with a raft of other such reforms. Of course, the only way to completely resolve these kinds of issues is to confront them with data that are capable of distinguishing between competing theories. Recent studies of liberalization that move from aggregate to firm-level data show the way forward.

\section{Firm-Level Perspectives on Capital Account Liberalization}

Perhaps the most important shortcoming of aggregate data is its limited ability to help us understand whether countries that liberalize efficiently allocate the capital that flows in. While the rise in aggregate stock prices and investment documented in the literature suggests that

\footnotetext{
${ }^{29}$ Gallindo, Schiantarelli, and Weiss (2005) provide some of the first evidence on this subject of which I am aware.
} 
liberalization promotes some efficient movement of capital between countries, it says nothing about the efficiency of capital allocation within countries. Within-country efficiency would require that the stream of capital from developed countries get allocated to the highest return sectors within the emerging economies to which it flows.

The efficiency of capital allocation is closely related to the cost of capital. For instance, the larger the fall in a country's cost of capital, the more its investment should increase. In other words, cross-country changes to investment in the aftermath of liberalizations should be negatively correlated with cross-country changes in the cost of capital on impact. The problem is that the small-sample-size problem inherent in the policy-experiment approach once again does not provide sufficient power to say anything meaningful about the empirical relevance of this hypothesis.

Similarly, aggregate data are of little use in helping us understand the role of international risk sharing, a subject that also has important efficiency implications and is of broad interest in the literature. ${ }^{30}$ Because the cost of capital matters for investment and risk sharing matters for the cost of capital, it is natural to wonder about the importance of risk sharing relative to the fall in the interest rate for the overall change in liberalizing countries' cost of capital. Unfortunately, studies of liberalization that use aggregate data provide no help on this point. For each country, aggregate data supply one observable proxy for the change in the cost of capital-the stock market revaluation discussed in Section 5. But there are two forces at work: the change in risk sharing and the change in the interest rate. Since one data point is not sufficient to identify two effects, it is impossible to disentangle them using aggregate data.

Firm-level data, on the other hand, provide more than sufficient degrees of freedom with

\footnotetext{
${ }^{30}$ For surveys of the literature on international risk sharing see Obstfeld and Rogoff (1996), chapter 5.
} 
which to disentangle the impact of risk sharing from the interest rate. This section reviews how recent work uses such data to gain a better understanding of risk sharing and the allocation of capital within countries. More generally, this section explains how recent firm-level studies enhance our understanding of the real effects of liberalization.

\section{A. Risk Sharing and Asset Prices}

The country-level organizing framework in Section 5A extends naturally to a firm-level setting that lays bare the risk-sharing content of stock price revaluations. The key idea is that the changes that occur in firms' stock prices at the time of liberalization embody signals about the impact of liberalization on the firms' fundamentals. If capital allocation is efficient, then firms' investment decisions should respond to these signals.

An efficient allocation of capital is one that satisfies the first-order condition for investment. Recall that before liberalization occurs the first-order condition for aggregate investment requires the expected marginal product of the aggregate capital stock to be equal to the aggregate cost of equity capital plus the rate of depreciation. The difference between the first-order condition for the economy as a whole and that for an individual firm lies in the equity premium. Whereas the aggregate equity premium is proportional to the variance of the return on the domestic market, $\operatorname{Var}\left(\tilde{r}_{M}\right)$, the equity premium for an individual firm, is proportional to the covariance of the firm's return with the local market.

Written in symbols to express it more concisely, the first-order condition for an individual firm's investment before liberalization is:

$$
f_{i}^{\prime}(k)^{e}=r+\gamma \operatorname{COV}\left(\tilde{r}_{i}, \tilde{r}_{M}\right)+\delta
$$

where the $i$ subscripts indicate that we are now talking about a single firm instead of the entire 
economy. Liberalizing a country's stock market changes the relevant source of systematic risk for pricing a firm's shares from the local stock market index to a world stock market index. Due to this change, the first-order condition for investment after liberalization is:

$$
f_{i}^{\prime}\left(k^{*}\right)^{e}=r^{*}+\gamma \operatorname{COV}\left(\tilde{r}_{i}, \tilde{r}_{W}\right)+\delta
$$

Where $\operatorname{COV}\left(\tilde{r}_{i}, \tilde{r}_{W}\right)$ is the covariance of firm i's return with the world market. Subtracting equation (12) from equation (11) gives a useful expression for the change in the first-order condition from before-to-after liberalization:

$$
\Delta f_{i}^{\prime}(k)^{e}=\left(r-r^{*}\right)+\gamma D I F C O V_{i}
$$

where $\operatorname{DIFCOV} V_{i}=\operatorname{COV}\left(\tilde{r}_{i}, \tilde{r}_{M}\right)-\operatorname{COV}\left(\tilde{r}_{i}, \tilde{r}_{W}\right)$.

The right-hand-side of equation (13) highlights the two channels through which liberalization changes a firm's cost of capital. Moving from left to right, the first term is exactly the same as in the aggregate case: a fall in the risk-free rate as the country switches from financial autarky to financial integration with the world market; this is a common shock to all firms in the economy. The second effect is unique to each firm: the greater the covariance of the firm's stock return with the local market relative to the covariance of its return with the world market, the larger the change in the firm-specific component of its cost of capital.

If liberalization does not alter the firm's expected future cash flow, the response of firm $i$ 's stock price to the news of the liberalization will mirror the change in its cost of capital. The firm's stock price will increase if liberalization reduces the cost of capital and vice versa. In other words, equation (13) predicts that each firm's revaluation will have an intercept term and a slope term. The intercept term should be the same across all firms within a given country. As for the slope effect, if risk sharing matters, then the revaluations that firms experience should be an increasing function of the variable DIFCOV. 
Recent work supports the two asset-pricing predictions of equation (13). Firms experience significant stock price revaluations during liberalizations (Chari and Henry, 2004; Patro and Wald, 2005). Furthermore, the stock price change associated with liberalization is positively and significantly related to $D I F C O V$. In a sample of 430 firms from 8 countries, the average firm-level revaluation is about 15 percent in real dollar terms, changes in firm-specific covariances explain roughly one-third of the revaluation, and the common shock is the same for all firms (Chari and Henry, 2004).

The finding that stock prices of firms in emerging markets move in accordance with changes in systematic risk provides some of the first empirical support for the CAPM in a domestic or international setting. ${ }^{31}$ It also runs counter to recent work which finds that stock returns in emerging economies generally contain little firm-specific information (Morck, Yeung, and $\mathrm{Yu}, 2000)$. These two facts make you wonder whether the firm-level asset pricing results are spurious. Two observations suggest otherwise.

First, the empirical design of the firm-level policy-experiment approach gives it power to uncover cross-sectional relationships between expected returns and systematic risk that are difficult to detect in other settings. Covariances are measured with error (Fama and French, 2004), and measurement error reduces the statistical power of any regression. Instead of testing for a relationship between levels of returns and levels of systematic risk, the firm-level policyexperiment approach focuses on episodes where there are large changes in both risk and returns. The magnitude of the liberalization-induced changes in expected returns and systematic risk associated with opening up the economy to foreign capital flows may simply dominate the attenuating effects of measurement error that usually plague efforts to find cross-sectional

\footnotetext{
${ }^{31}$ For discussions of the CAPM's empirical record, see Fama (1991), Cochrane (1999), and Campbell (2000). Karolyi and Stulz (2001) discuss the international CAPM.
} 
pricing relationships. Similarly, changes in emerging-market stock prices may convey little firm-specific information in general, but they do convey such information during episodes like liberalizations when the magnitude of the information is sufficiently large. ${ }^{32}$

Second, using a similar approach to that of Chari and Henry (2004), Dvorak and Podpiera (2005) also find that large changes in systematic risk have explanatory power for changes in the cross-section of expected returns. The policy experiment that provides the key source of variation for Dvorak and Podpiera's exercise is the addition of eight central and Eastern European countries into the European Union in 2001. Dvorak and Podpiera (2005) argue that accession into the European Union integrated the stock markets of the acceding countries with the rest of Europe and thereby changed the source of systematic risk facing investors in the countries that gained membership. In their sample of 74 firms, the difference between the beta of a firm's stock return with the local market and its beta with the European market explains about 22 percent of the typical stock price revaluation that occurs with accession.

\section{B. Risk Sharing and Resource Allocation}

While the correlation between changes in returns and changes in systematic risk provide some evidence of within-country efficiency at the level of asset pricing, the more pressing question is whether real resource allocation-investment-responds accordingly. ${ }^{33}$ As the benchmark for determining the firm's investment hurdle rate switches from the local stock market index to a world stock market index, efficiency requires that allocation of the firm's physical capital also shift in accordance with the change in the source of the country's systematic

\footnotetext{
${ }^{32}$ The firm-specific information in stock prices also rises as countries adopt greater capital market openness (Li, Morck, Yang, and Yeung, 2004).

${ }^{33}$ The idea of trying to relate changes in investment to the liberalization-induced changes in stock prices follows in the spirit of earlier work that tries to relate changes in investment to changes in stock prices more generally

(Blanchard, Rhee, and Summers, 1993; Fischer and Merton, 1984; Tobin and Brainard, 1977).
} 
risk. $^{34}$ In order to restore equilibrium, the increase in the firm's capital stock must be large enough to drive the expected marginal product down to the lower, post-liberalization cost of capital. Equation (13) implicitly defines the size of the required increase and therefore delivers two testable predictions about investment.

The first prediction is that the common shock to the cost of capital should cause the average investment rate of all firms to rise. The second prediction is that, given the common shock, the firm-specific shock (the change in covariance) implies that firms whose equity premia fall should invest even more than those whose premia rise. In other words, if physical capital is reallocated in line with the optimal smoothing of production risk, then high DIFCOV firms should experience faster capital stock growth than low DIFCOV firms following liberalization.

The first prediction about liberalization and firm-level investment finds empirical support in the literature. The growth rate of the average firm's capital stock exceeds its pre-liberalization mean by an average of 3.8 percentage points per year (Chari and Henry, 2006). This effect is much larger than the corresponding increase in the aggregate capital stock over the same time period (1.1 percentage points per year). Because stock market liberalizations most directly affect the investment incentives of publicly traded firms, the firm-level investment results are more credible than the aggregate results and make a stronger case that liberalization does, indeed, have real effects. $^{35}$

The second prediction about liberalization and firm-level investment enjoys rather less empirical success. There is no evidence that physical investment responds to changes in systematic risk, and firm-specific changes in equity premia (the DIFCOV variable) have an

\footnotetext{
${ }^{34}$ For a helpful exposition on the resource-allocation implications of changes in systematic risk, see Tesar and Werner (1998), pp. 290-292.

${ }^{35}$ The firm-level investment data used by Chari and Henry (2006) comes from the International Finance Corporation's Corporate Finance Database. For a detailed description of this dataset, see Demirguc-Kunt, and Maksimovic (1998) and Booth, Aivazian, Demirguc-Kunt, and Maksimovic (2001).
} 
economically trivial and statistically insignificant effect on changes in investment.

The finding that firms' investment decisions are insensitive to firm-specific changes in their cost of capital delivers a powerful blow to the Allocative Efficiency view of liberalization. On the other hand, with little evidence from developed markets to suggest that exposure to aggregate covariance risk drives expected returns, testing the hypothesis that firms in developing countries allocate physical investment in accordance with the CAPM may seem to fly in the face of all common sense.

But if the risk-sharing-resource-allocation hypothesis is a straw man, then it is a very popular one. Virtually all studies of international risk sharing lean heavily on the intuition that the gains to trade in risky assets stem from the difference between the variance of domestic returns (consumption) and the covariance of domestic returns (consumption) with the rest of the world (see, for example, Athanasoulis and Van Wincoop, 2000; Obstfeld and Rogoff, 1996, chapter 5; Lewis, 1999, 2000; Van Wincoop, 1994, 1999). Furthermore, we have just seen that firm-level stock prices do move in conjunction with liberalization-induced changes in systematic risk. So the real issue is why the reductions in risk premia do not cause firms to adopt projectsa lá Obstfeld (1994) — that were too risky to undertake in the absence of international risk sharing.

However one chooses to interpret the evidence, an important limitation of existing firmlevel studies on the benefits of risk sharing is their exclusive focus on: (a) the production side of the economy (i.e., investment) and (b) the removal of restrictions on capital inflows. The largest future welfare gains to capital account liberalization in developing countries such as China and India are likely to come from the reduction in consumption and income volatility that will occur when their governments liberalize capital outflows, thereby permitting their citizens to hold 
assets abroad and unload some of the systematic risk of the domestic economy. This is not a new point (see Lessard, 1973, 1994), but the glaring absence of empirical research on the welfare impact of liberalizing capital outflows practically cries out for an application of the policyexperiment approach. Given the problems with aggregate consumption data (especially in developing countries), substantial contributions in the area of risk sharing and liberalization are most likely to come from analyses that use the cross-sectional variation in firm-level data in conjunction with major policy changes to construct convincing identification strategies.

\section{C. Other Firm-Level Approaches to Liberalization and Efficiency}

Testing whether liberalization-induced changes in risk drive changes in asset prices and investment provides one way of evaluating efficiency, but it is also useful to adopt a broader perspective-one that is grounded in theory but not tied so restrictively to the CAPM. There is much to be learned about the impact of capital account policy on real variables by looking at firm-level data from a number of different perspectives.

For instance, another way to tackle the question of liberalization and allocative efficiency is to turn the policy-experiment approach on its head. In addition to looking at how firms respond to liberalization, it may be just as instructive to study how firms respond when countries impose restrictions on capital inflows (Forbes, 2006). If capital account liberalization enhances efficiency, then imposing capital controls should diminish efficiency in at least two important ways. First, capital controls may reduce the supply of capital, thereby raising the cost of borrowing and tightening the financing constraints faced by domestic firms. Second, by reducing the supply of capital, capital controls can decrease competition and market discipline, permitting firms that might not survive if their competitors had access to credit to flourish behind 
closed borders (Rajan and Zingales, 2003; Johnson and Mitton, 2002, Morck, Strangeland, and Yeung, 2000).

A number of papers examine the extent to which the presence of capital controls exacerbates the financing constraints faced by various kinds of firms. In the spirit of Fazzari, Hubbard, and Petersen (1988), the basic test involves the examination of the sensitivity of investment to cash flow. ${ }^{36}$ Forbes (2003) uses El Encaje, the Chilean episode of taxes on capital inflows from 1991 to 1998 , as a policy experiment with which to assess the efficiency implications of capital controls. ${ }^{37}$ Her analysis begins with the following observation. In developed countries, small, publicly traded firms exhibit higher investment growth than large, publicly traded firms. Forbes (2003) finds that this is also the case in Chile before 1991 and after 1998. During El Encaje, however, she finds that the investment growth of small firms drops below that of large firms. She goes on to show that El Encaje increased the sensitivity of investment to cash flow for small, publicly traded firms whereas the sensitivity of large firms was unaffected.

In contrast to Forbes' case study, Harrison, Love and McMillan (2004) use a crosscountry, firm-level panel data set to study the impact of capital account restrictions. They take their measures of capital account restrictions from the IMF publication AREAER discussed in Section 3. Like Forbes (2003), they find that the presence of capital account restrictions increases the sensitivity of firms' investment to cash flow. They also document that the sensitivity of domestically-owned firms' investment to cash flow is greater than that of firms with foreign ownership or assets.

In a paper that reverts back to the easing of capital controls, Laeven (2003) constructs a

\footnotetext{
${ }^{36}$ For a detailed discussion of the literature on financing constraints and investment, see Hubbard (1998).

${ }^{37}$ Gallego and Hernandez (2003) also conduct an analysis of el Encaje.
} 
cross-country data set to address the question of whether financial liberalization eases financing constraints and increases competition. Financial liberalization typically refers to the removal of interest rate ceilings, directed credit, and other such distortions in the domestic financial markets. ${ }^{38}$ Laeven's paper has implications for capital-account liberalization because his measure of financial liberalization captures the impact of foreign direct investment (i.e., foreign entry) into the domestic banking sector. As such, it has some power to speak to the issue of whether foreign bank entry increases the supply of capital and makes the domestic lending market more competitive. He finds that the sensitivity of small firms' investment to cash flow falls by 80 percent as a result of financial liberalization. He also finds that the investment of large firms becomes more sensitive to cash flow after financial liberalization and interprets this finding as evidence that large firms may have had access to preferential credit before financial liberalization.

One important weakness of firm-level papers that examine the efficiency implications of capital controls is their interpretation of the sensitivity of investment to cash flow as a measure of firm-financing constraints. If firms face financing frictions then their investment will be sensitive to cash flow. But the converse of the preceding statement need not be true: Sensitivity of investment to cash flow does not imply that firms face financial constraints (Kaplan and Zingales, 1997, 2000; Stein, 2003).

While there are multiple interpretations of the investment-cash-flow sensitivity of emerging-market firms, and it remains to be seen how all of the results reviewed in this section will stand up to further scrutiny, there is little question that papers which use firm-level data provide two steps forward: (1) They increase our understanding of the transmission mechanisms

38 See McKinnon (1973), Shaw (1973), and Diaz Alejandro (1985). 
through which capital-account policy affects the real economy, and (2) they provide a blueprint of how to construct firm-level identification strategies for disentangling those mechanisms.

\section{Do Liberalizations Cause Crises?}

Stock market liberalizations deliver undeniable benefits over the short-to-medium term, but viewed over a more extensive horizon, the data raise questions about the longer-run costbenefit tradeoff. For instance, extending Figures 4 and 5 to ten years beyond the liberalization dates in Table 1 would reveal the collapse in investment and output associated with the Asian Crisis. In addition to its effect on real variables, there is the additional question of whether liberalizations also amplify the cycle in asset prices (Kaminsky and Schmukler, 2002). For instance, in contrast to the efficient-markets prediction that there should be no revaluation of assets once markets are open to foreign investors, equity prices continue to rise for two to three years after stock market liberalizations, but then lose significant value over the longer term (Martell and Stulz, 2003). At first glance, the boom-bust cycle in output, investment and asset prices seems consistent with the view that liberalizations cause crises, but there are at least three important points to keep in mind.

First, crises occur not in only in countries that liberalize the capital account, but also in those where capital controls are in place (Forbes, 2006). There is, in fact, some systematic evidence that the occurrence of crises and the imposition of capital controls are positively correlated (Glick and Hutchinson, 2000; Eichengreen, 2003). So it is equally plausible that bad policy precipitates crises and countries impose capital controls as a way to postpone the financial-market consequences (such as depreciation of the currency) of weak or deteriorating fundamentals. In other words, at least some of the existing evidence supports the notion that 
poor macroeconomic policies, not capital account liberalizations, cause crises.

Second, when trying to determine whether liberalizations or fundamentals cause crises, it is important to think critically about timing. The median stock market liberalization date in Table 1 is 1989-five years prior to the Mexican crisis of December 1994 and almost 10 years before the Asian crisis of 1997. Given the length of time between the onset of stock market liberalizations and the rash of subsequent emerging-market financial crises, any causal link between the two is far from obvious. Of course, the seeds of a misguided policy may take a long time to yield their bitter fruit, so lags in timing alone cannot dismiss the possibility that stock market liberalizations played a role. Nevertheless, the more proximate and plausible cause of the crises would appear to be the build-up of short-term dollar-denominated debt: tesobonos in the case of Mexico and interbank loans in the case of Asia (Krueger, 2000; Mishkin, 1996, 2000).

The question of whether stock market liberalizations or short-term debt caused the Mexican and Asian crises raises the third and most important point: Cost-benefit analyses of capital account liberalization do not make sense without specifying exactly what is meant by the term "capital account liberalization." In its broadest form, a capital account liberalization can be any decision by a country's government that allows capital to flow more freely in and (or) out of that country. Allowing domestic businesses to take out loans from foreign banks, permitting foreigners to purchase domestic government debt instruments, and allowing foreigners to invest in the domestic stock market are but three examples. At a minimum, we need to distinguish between two categories of liberalization: those that involve debt and those that involve equity. The distinction matters, because the answer to the question, "do liberalizations cause crises?" depends critically on whether you are talking about the liberalization of debt or equity flows. 


\section{A. The Importance of Distinguishing Debt from Equity}

A debt contract requires regular payments, regardless of the borrower's circumstances. This means that when bad news arises, creditors rush to get their money while they can. An equity contract, on the other hand, involves risk-sharing — large payouts for shareholders when times are good and little to nothing when times are bad. It may seem that foreign purchase of equities on the domestic stock market could be reversed if and when foreign investors become concerned about a country's prospects, but shareholders cannot simply demand their money back. They have to sell their shares, and prices will drop as soon as other market participants (domestic or foreign) anticipate the increase in supply. Furthermore, as prices fall, expected returns rise so that the incentive to sell equity is no longer as strong (Choe, Kho, and Stulz, 1999). In other words, servicing an equity contract involves procyclical payments that tend to stabilize the balance of payments, whereas debt service payments are countercyclical and therefore have the opposite effect.

Because it does not embody risk-sharing, excessive reliance on debt can cause financial distress. In the 1970s developing-country governments obtained large quantities of floating-rate commercial bank loans. The Debt Crisis of the 1980s then demonstrated that debt contracts can induce large inefficiencies when economic conditions turn out to be worse than anticipated at the time the contract was signed (Fischer, 1987). Nor is it simply the flow of asset-service payments that is more likely to vary in a stabilizing way for equity than for debt. "The debt crisis was caused most immediately and powerfully by the cutoff in new lending without any similar curb on the requirement to pay amortization" (Williamson, 1997, p. 288).

Williamson's point about the cessation of new lending gains particular saliency in the context of the further distinction between bonds and bank loans. The nature of bank lending 
makes that form of capital flows far more volatile than portfolio bond or equity flows. For instance, domestic banks borrow short-term in the foreign interbank market with the expectation that they will be able to roll over the loans. The potential problems here are twofold. First, the decision by lenders to call in loans and cease rolling them over tends to be driven not by idiosyncratic shocks to individual borrowers but common shocks to the domestic economy (Dobson and Huffbauer, 2001). Second, common shocks dominate idiosyncratic shocks in emerging markets (Morck, Yeung, and Yu, 2000). Taken together, these two facts create the potential for large-scale reversals of short-term interbank loans.

Yet the vast majority of bank lending to emerging markets takes the form of short-term bank loans (loans with a maturity of less than a year). At the end of 1997, 55 percent of foreign bank loans world-wide were short-term, and one third of these loans were of the interbank variety. For instance, foreign capital slows to Thailand peaked at 25.5 billion dollars in 1995; 75 percent of this sum took the form of bank loans; two thirds of these loans had maturities of less than a year, and the majority went to Thai banks and nonbank financial intermediaries (Baily, Farrell, and Lund, 2000).

The critical point about interbank loans is that they may be used by the recipient banks to make loans to finance domestic projects that may not be short-term, thereby creating a liability mismatch. These liability mismatches wreak havoc on the domestic economy in the face of external shocks. Excessive short-term borrowing in dollars from foreign banks by Asian banks, companies, and governments played a central role in the onset of the Asian Financial Crisis (Furman and Stiglitz, 1998; Radelet and Sachs, 1998). In essence, the mismatch between the term structure of Asian borrowers' assets (long term) and their dollar-denominated external liabilities (short term) meant that any bad news that made their lenders reluctant to extend new 
loans was bound to create a liquidity problem.

The tendency toward sudden reversal of short-term bank flows underscores the central point of the discussion. Whereas portfolio flows adjust to shocks through changes in prices, short-term bank loans adjust through quantities (Dobson and Huffbauer, 2001). Consequently, bank lending to emerging markets is far more volatile than portfolio investment in bonds or equities (Kose et al., 2006). Again, the Asian Crisis highlights the difference in volatility. In 1996, the five Asian Crisis countries (Indonesia, Malaysia, Philippines, South Korea, Thailand) received 47.8 billion dollars of capital inflows in the form of bank loans; in 1997, they experienced a collective outflow of 29.9 billion dollars - a reversal of almost 80 billion dollars in a one-year period (Baily, Farrell, and Lund, 2000).

In contrast to the abrupt reversal in bank flows, portfolio flows remained positive in Asia throughout 1997. Baily, Farrell, and Lund (2000) document that aggregate portfolio flows to the crisis countries fell by about half but remained positive. Furthermore, the aggregate pattern holds at the individual country level for South Korea, Malyasia, and Thailand. In the case of Thailand, even as foreign banks were refusing to roll over loans, portfolio flows increased by 70 percent between the second and third quarters of 1997 and remained positive through the first half of 1998. The authors document that Indonesia did experience net portfolio outflows in the fourth quarter of 1997, but they turned positive again by the middle of 1998 .

Beyond the Asian crisis, heavy short-term borrowing in dollars played a central role in precipitating almost every emerging-market financial crisis during the 1990s (Dornbusch, 2000; Feldstein, 2002). A general finding is that the ratio of short-term debt to reserves predicts crises, and greater short-term exposure predicts more severe crises when positive capital flows turn negative (Rodrik and Velasco, 2000). 


\section{B. If Debt Is So Risky, Why Do We See So Much of It?}

Table 4 illustrates the dominance of debt over equity by breaking the composition of capital flows to developing countries into five major categories: public and publicly guaranteed debt flows, private nonguaranteed debt flows, foreign direct investment (FDI), portfolio equity, and grants. The sum of the first two categories reflects all debt flows. From 1970 to 1984, debt typically accounted for about 80 percent of all capital flows to developing countries. If debt constitutes such a dangerous form of lending, why do we do we see so much of it relative to equity? One obvious reason follows directly from the discussion in Section 5: Prior to the latter half of the 1980s, developing countries largely banned foreigners from holding domestic shares.

If debt is so risky relative to equity, then why do governments liberalize debt inflows by removing restrictions on offshore borrowing by domestic banks, while retaining hard limits on foreign participation in the equity market? There are number of competing explanations for the relatively slow liberalization of equity markets, all of which deserve more serious consideration than the speculative treatment I give them in the next few sentences. Domestic capitalists in the nonfinancial sector of the economy may favor liberalization because it reduces their cost of capital. But these capitalists may also be reluctant to create the necessary preconditions for successful equity market liberalization (Shleifer and Wolfenzon, 2002). Alternatively, there may be competing interests. Liberalization generates aggregate welfare gains, but there may also be potential losers who oppose the process (Rajan and Zingales, 2003). For example, domestic banks may lose monopoly rents because liberalizations provide domestic firms with alternative sources of financing. In turn, large, nonfinancial firms may be worse off because new sources of financing for their smaller, more financially constrained industry peers may increase product market competition. Finally, governments may delay equity market liberalizations for an 
entirely different set of considerations. Future research should address these issues.

Whatever explains the delay, with the advent of stock market liberalization, portfolio equity as a fraction of total capital inflows rose from less than 0.1 percent in 1980-84 to 18.7 percent in 1990-95-an increase of almost two-hundredfold. Debt as a fraction of total capital flows fell from 82 percent in 1980-84 to 50 percent in 1990-95. FDI flows as a fraction of total capital flows increased from 13 percent in 1980-84 to 28 percent in 1990-95. However, the flow of portfolio equity to emerging markets has slowed since the boom of the early 1990s (Akyut, Kalsi, and Ratha, 2003). And while developing countries' ratios of external debt to equity fell between 1997 and 2001, it is still not clear that they have fallen to prudent levels (Suttle, 2003, p. 9). Hence, the recent increase in portfolio equity and FDI inflows, notwithstanding, developing countries still lean heavily towards debt. ${ }^{39}$

The observed pattern of debt and equity flows is an equilibrium outcome, resulting from the optimal response of borrowers and lenders to a given set of institutional arrangements. Therefore, the critical issue is what distortions in the international financial system produce incentives that lead to so much debt and so little equity. One prominent example of an incentivedistorting institutional arrangement was the Basel Capital Accord of 1988 (Basel I).

Drafted in response to the 1980 s debt crisis, Basel I tried to reduce systemic risk by linking banks' capital adequacy ratios to the riskiness of their loans. Under Basel I, banks had to set aside capital equal to at least 8 percent of their risk-adjusted assets to provide a buffer in case of a loss on those assets. The problem was that Basel I's system for risk-adjusting assets created an unintentional bias toward short-term lending to emerging markets. Lending to banks in OECD countries received a 20-percent risk weighting, regardless of the maturity structure of the

\footnotetext{
${ }^{39}$ Home bias, the fact that foreign investors hold fewer foreign securities than they should, does not explain why the composition of securities they do hold favors debt so strongly. Lewis (1999) surveys the home-bias literature.
} 
loan. For loans to non-OECD countries, short-term loans received a 20-percent weight, longterm loans a 100-percent weight (Bonte, 1999).

As a consequence of Basel I's weighting system, short-term, foreign currency lending to banks in emerging markets required only one fifth of the capital required of long-term loans to banks in emerging markets, and no more capital than a long-term loan to a bank in an OECD country. Skewing the incentive structure for banks in G-10 countries to lend short-term to emerging markets had predictable consequences. As discussed in Section 8A, short-term, dollardenominated loans, most of which originated with European and Japanese banks, constituted the lion's share of debt contracts in the East Asian Crisis. The introduction of Basel II in 1999 may help alleviate the bias towards short-term debt in Basel I, but Rogoff (1999) identifies three other sources of debt bias in the international financial system not directly related to capital adequacy ratios.

First, by making it less risky to hold deposits, deposit insurance in creditor and debtor countries increases the deposit base and expands the size of the banking system. Implicit subsidies are also a problem. As the size of banking system expands, it becomes increasingly difficult for the government to credibly commit to not bail out the banking system in the event of a financial meltdown (Akerlof and Romer, 1993). Somewhat perversely, deposit insurance may also raise the probability of bank failures by reducing the incentive for depositors to monitor the lending practices of the financial institutions where they keep their money. ${ }^{40}$

Second, the international financial system protects the rights of debt holders more vigilantly than those of equity holders. G-7 lenders to emerging-market countries can resort to G-7 courts in the event of a debt dispute, but there is no such avenue of recourse for G-7 holders

\footnotetext{
${ }^{40}$ Rogoff (1999) also argues that funds from international financial institutions aimed at helping distressed-country debtors also provide an implicit subsidy to G-7 debt holders that encourages debt financing over equity.
} 
of emerging-market equity (Bulow, 2002; Rogoff, 1999; Obstfeld, 1998).

Third, the underdevelopment of equity markets in emerging economies exacerbates the problem of preferential treatment of debtholders in G-7 courts. The point here is closely related to the discussion in Section 6A.3. A lack of transparency in emerging equity markets makes foreigners reluctant to invest, and weak protection of the rights of equity investors reinforces the tendency of capital suppliers to purchase debt instead of equity (Henry and Lorentzen, 2003).

\section{Conclusion}

Writing about capital account liberalization in 1998, Jagdish Bhagwati threw down the gauntlet, declaring that "It is time to shift the burden of proof from those who oppose to those who favor liberated capital" (Bhagwati, 1998). The explosion of papers written on the subject since that time indicates the seriousness with which the profession has taken his challenge.

There is little evidence that economic growth and capital account openness are positively correlated across countries. But there is lots of evidence that opening the capital account leads countries to temporarily invest more and grow faster than they did when their capital accounts were closed. Why does so much of the literature focus on the relationship between openness and long-run growth when the predictions of the neoclassical model all point toward the short-run impact of a country opening up? Part of the answer is tradition. Cross-sectional regressions of national growth rates on policy variables have been around for a while, so the gravitational pull of that methodological approach is quite strong. But I also think that the answer has something to do with a professional obsession. There has always been a great deal of interest in uncovering policies that increase the steady-state rate of growth. As a consequence, economists tend to ignore the importance of short-run increases that permanently raise the path of national income to a higher, but parallel trajectory (Solow, 2000, pp. 182-83). 


\section{References}

Abdelal, Rawi and Laura Alfaro. 2002. "Malaysia: Capital and Control," Harvard Business School Case 702-040.

Abdelal, Rawi and Laura Alfaro. 2003. "Capital and Control: Lessons From Malaysia," Challenge 46(4), 36-53.

Aitken, Brian and Ann Harrison. 1999. "Do Domestic Firms Benefit From Direct Foreign Investment? Evidence from Venezuela," American Economic Review, 89(3), 605-618.

Akerlof, George and Paul M. Romer. 1993. "Looting: The Economic Underworld of Bankruptcy for Profit," Brookings Papers on Economic Activity 2, 1-74.

Akyut, Dilek, Himmat Kalsi, and Dilip Ratha. 2003. "Sustaining and Promoting Equity-Related Finance for Developing Countries," Global Development Finance: Striving for Stability in Development Finance, Washington: World Bank.

Alfaro, Laura and Eliza Hammel. 2006. "Capital Flows and Capital Goods,” Harvard Business School Working Paper.

Alfaro, Laura, Sebnem Kalemi-Ozcan, and Vadym Volosovych. 2006. "Why Doesn't Capital Flow From Rich to Poor Countries? An Empirical Investigation" in Capital Controls and Capital Flows in Emerging Economies: Policies, Practices, and Consequences, Sebastian Edwards (ed.) University of Chicago Press, Forthcoming.

Alesina, Alberto, Vittorio Grilli, and Gian-Maria Milesi-Feretti. 1994. "The Political Economy of Capital Controls" in Capital Mobility: The Impact on Consumption, Investment and Growth, L. Leiderman and A. Razin (eds.), Cambridge, New York and Melbourne: Cambridge University Press, 289-321.

Arslanalp, Serkan and Peter Blair Henry .2005. "Is Debt Relief Efficient?” Journal of Finance, 60(2), 1021-1055.

Arslanalp, Serkan and Peter Blair Henry. 2006a. "Debt Relief," Journal of Economic Perspectives, 20(1), 207-220.

Arslanalp, Serkan and Peter Blair Henry. 2006b. "Helping the Poor to Help Themselves: Debt Relief or Aid?" in Sovereign Debt at the Crossroads, Chris Jochnick and Fraser A. Preston (eds.), Oxford University Press, 174-193.

Arteta, Carlos, Barry Eichengreen, and Charles Wyplosz. 2001. "When Does Capital Account Liberalization Help More Than It Hurts?" NBER Working Paper No. 8414.

Athanasoulis, Stefano and Eric Van Wincoop. 2000. "Growth Uncertainty and Risk Sharing" 
Journal of Monetary Economics, 45, 477-505.

Baily, Martin, Diana Farrell, and Susan Lund. 2000. "The Color of Hot Money," Foreign Affairs, 79, 99-109.

Barro, Robert. 1991. "Economic Growth in a Cross-Section of Countries," Quarterly Journal of Economics, 106(2), 407-443.

Barro, Robert J. and Xavier Sala-I-Martin. 1995. Economic Growth, New York: McGraw Hill.

Bekaert, Geert and Campbell R. Harvey. 2000. "Foreign Speculators and Emerging Equity Markets," Journal of Finance, 55(2), 565-613.

Bekaert, Geert, Campbell Harvey and Christian Lundblad. 2005. "Does Financial Liberalization Spur Growth?” Journal of Financial Economics, 77(1), 3-55.

Bhagwati, Jagdish. 1998. “The Capital Myth,” Foreign Affairs, 77, 7-12.

Blanchard, Olivier J., C. Rhee, and Lawrence Summers. 1993. "The Stock Market, Profit, and Investment," Quarterly Journal of Economics, 108, 115-136.

Bonte, Rudi. 1999. "Supervisory Lessons to Be Drawn From the Asian Crisis." Basel Committee on Supervision Working Papers, No. 2.

Booth, Laurence, Varouj Aivazian, Asli Demirguc-Kunt, and Vojislav Maksimovic. 2001. "Capital Structures in Developing Countries," Journal of Finance, 56(2), 87-130.

Bosworth, Barry and Susan Collins. 2003. "The Empirics of Growth: An Update" Brookings Papers on Economic Activity, 2, 113-206.

Bruno, Michael, and William Easterly. 1998. "Inflation Crises and Long Run Growth,” Journal of Monetary Economics, 41(1), 3-26.

Bulow, Jeremy. 2002. "First World Governments and Third World Debt," Brookings Papers on Economic Activity, 1, 229-255.

Bulow, Jeremy and Lawrence Summers. 1984. "The Taxation of Risky Assets," Journal of Political Economy, 92(1), 20-39.

Calderon, Cesar, Norman Loayza, and Klaus Schmidt-Hebbel. 2004. "Openness, Vulnerability, and Growth,” Working Paper, Central Bank of Chile.

Calvo, Guillermo and Carlos Végh. 1998. "Inflation Stabilization and Balance of Payments Crises in Developing Countries" in Handbook of Macroeconomics, John Taylor and Michael Woodford, (eds.) Amsterdam: North-Holland. 
Campbell, John. 2000. “Asset Pricing at the Millennium” Journal of Finance, Vol. 55 (4) 1515-1567.

Caselli, Francesco. 2005. "Accounting for Cross-Country Income Differences" in Peter Aghion and Steven Durlauf eds. The Handbook of Economic Growth, North Holland.

Caselli, Francesco and James Feyrer. 2006. "The Marginal Product of Capital” Quarterly Journal of Economics, forthcoming.

Chari, Anusha and Peter Blair Henry. 2004. "Risk Sharing Asset Prices: Evidence From a Natural Experiment," Journal of Finance, 59(3), 1295-1324.

Chari, Anusha and Peter Blair Henry. 2006. "Firm-Specific Information and the Efficiency of Investment," NBER Working Paper No. 12186.

Chari, Anusha, Page Ouimet, and Linda Tesar. 2004. "Acquiring Control in Emerging Markets: Evidence from the Stock Market," NBER Working Paper No. 10872.

Chinn, Menzie and Hiro Ito. 2002. "Capital Account Liberalization, Institutions, and Financial Development: Cross Country Evidence,” NBER Working Paper No. 8967.

Choe, Hyuk, Bong-Chan Kho, and René M. Stulz. 1999. "Do Foreign Investors Destabilize Stock Markets? The Korean Experience in 1997," Journal of Financial Economics 54(2), 227-264.

Claessens, Stijn and Moon-Whoan Rhee. 1994. "The Effect of Barriers to Equity Investment in Developing Countries" in The Internationalization of Equity Markets, Jeffrey A. Frankel, (ed.), University of Chicago Press, Chicago and London, 231-275.

Cochrane, John. 1999. "New Facts in Finance" Economic Perspectives Federal Reserve Bank of Chicago, 23 (3), 36-58.

Coval, Joshua and Tobias J. Moskowitz. 1999. "Home Bias at Home: Local Equity Preference in Domestic Portfolios," Journal of Finance, 54(1), 2045-2074.

Coval, Joshua and Tobias J. Moskowitz. 2001. "The Geography of Investment: Informed Trading and Asset Prices," Journal of Political Economy, 109(4), 811-841.

De Jong, Frank and Frans De Roon. 2005. "Time Varying Market Integration and Expected Returns in Emerging Markets," Journal of Financial Economics 78(3), 583-613.

Demirgüç-Kunt, Aslı and Vojislav Maksimovic. 1998. "Law, Finance, and Firm Growth," Journal of Finance 53(6), 2107-2136.

Diaz-Alejandro, Carlos F. 1985. "Goodbye Financial Repression Hello Financial Crash," Journal of Development Economics, 19, 1-24. 
Dobson, Wendy and Clyde Huffbauer. 2001. World Capital Markets: Challenge to the G-10, Washington: Institute for International Economics.

Dornbusch, Rudiger. 1983. Panel discussion on the southern cone, International Monetary Fund Staff Papers, 30, 164-184.

Dornbusch, Rudiger. 2000. Keys to Prosperity: Free Markets, Sound Policy, and a Bit of Luck, MIT Press.

Dvorak, Tomas and Richard Podpiera. 2005. "European Enlargement and Equity Markets in Accession Countries," European Central Bank, Working Paper No. 552.

Easterly, William. 1996. “When Is Stabilization Expansionary?” Economic Policy, 22, 67-107.

Edison, Hali, Ross Levine, and Torsten Sløk. 2002. "International Financial Integration and Economic Growth," Journal of International Money and Finance, 21, 749-776.

Edison, Hali, Michael Klein, Luca Ricci, and Torsten Sløk. 2004. "Capital Account Liberalization, and Economic Performance: Synthesis and Survey," IMF Staff Papers, 51(2), 220-256.

Edison, Hali and Francis Warnock. 2003. "A Simple Measure of the Intensity of Capital Controls," Journal of Empirical Finance, 10(1), 81-103.

Edwards, Sebastian. 1984. "The Order of Liberalization of the External Sector in Developing Countries," Princeton Essays in International Finance, 156.

Edwards, Sebastian. 2001. "Capital Mobility and Economic Performance: Are Emerging Economies Different?” NBER Working Paper No. 8076.

Eichengreen, Barry. 2001. "Capital Account Liberalization: What Do Cross-Country Studies Tell Us?” The World Bank Economic Review, 16(3), 341-365.

Eichengreen, Barry. 2003. Capital Flows and Crises, The MIT Press, Cambridge, MA.

Eichengreen, Barry. 2004. "Financial Instability" in Global Crises: Global Solutions, Bjorn Lomborg (ed.), Cambridge University Press.

Errunza, Vihang and Darius Miller. 2000. "Market Segmentation and the Cost of Capital" in International Equity Markets, Journal of Financial and Quantitative Analysis 35, 577600 .

Fama, Eugene F. 1991. "Efficient Capital Markets: II," Journal of Finance, Vol. 46(5), 15751617.

Fama, Gene and Ken French. 2004. "The CAPM: Theory and Evidence," Journal of Economic 
Perspectives, 18(3), 25-46.

Fazzari, Steven M., R. Glenn Hubbard, and Bruce C. Petersen. 1988. "Financing Constraints and Corporate Investment," Brookings Papers on Economic Activity, 1988(1), 141206.

Feldstein, Martin. 2002. "Economic and Financial Crises in Emerging Market Economies: Overview of Prevention and Management," NBER Working Paper No. 8837.

Fischer, Stanley. 1987. "Sharing the Burden of the Debt Crisis," American Economic Review, Papers and Proceedings 77(2), 165-170.

Fischer, Stanley. 1998. "Capital Account Liberalization and the Role of the IMF," Princeton Essays in International Finance 207, 1-10.

Fischer, Stanley. 2003. "Globalization and Its Challenges," American Economic Review, 93(2), $1-30$.

Fischer, Stanley and Robert C. Merton. 1984. "Macroeconomics and Finance: The Role of the Stock Market," Carnegie-Rochester Conference Series on Public Policy, 21, 57-108.

Fischer, Stanley, Ratna Sahay, and Carlos Végh. 2002. "Modern Hyper and High Inflations," Journal of Economic Literature 40(3), 937-980.

Foerster, S. and Andrew Karolyi. 1999. "The Effects of Market Segmentation and Investor Recognition on Asset Prices: Evidence From Stocks Listing in the U.S.” Journal of Finance, 54, 981-1014.

Forbes, Kristin. 2003. "One Cost of the Chilean Capital Controls: Increased Financial Constraints for Smaller Traded Firms," NBER Working Paper No. 9777.

Forbes, Kristin. 2006. "The Microeconomic Evidence on Capital Controls: No Free Lunch" in Capital Controls and Capital Flows in Emerging Economies: Policies, Practices, and Consequences, Sebastian Edwards (ed.) University of Chicago Press, Forthcoming.

Frankel, Jeffrey A. 1994. "Introduction" in The Internationalization of Equity Markets, Jeffrey A. Frankel (ed), Chicago and London: University of Chicago Press, 1-20.

Frankel, Jeffrey A. and David Romer. 1999. "Does Trade Cause Growth?" American Economic Review, 89(3), 379-399.

Furman, Jason and Joseph Stiglitz. 1998. "Economic Crises: Evidence and Insights from East Asia," Brookings Papers on Economic Activity, 2, 1-114.

Gallego, Francisco and Leonardo Hernandez. 2003. "Microeconomic Effects of Capital Controls: The Chilean Experience During the 1990s," International Journal of Finance and 
Economics, 8(3), 225-253.

Gallindo, Arturo, Fabio Schiantarelli, and Andrew Weiss. 2005. "Does Financial Liberalization Improve the Allocation of Investment? Micro Evidence from Developing Countries," Journal of Development Economics, forthcoming.

Glick, Reuven and Michael Hutchinson. 2000. "Stopping Hot Money or Signaling Bad Policy? Capital Controls and the Onset of Currency Crises," Federal Reserve Bank of San Francisco Working Paper.

Gordon, Myron. 1962. The Investment, Financing, and Valuation of the Corporation, Homewood, Illinois: Richard D. Irwin, Inc.

Gorg, Holger and David Greenaway. 2004. "Much Ado About Nothing? Do Domestic Firms Really Benefit from Foreign Direct Investment?" World Bank Research Observer, 19(2), 171-197.

Gourinchas, Pierre Olivier and Olivier Jeanne. 2006. "The Elusive Gains from International Financial Integration," Review of Economic Studies, forthcoming.

Grilli, Vittorio and Gian Maria Milesi-Ferretti. 1995. "Economic Effects and Structural Determinants of Capital Controls," IMF Staff Papers, 42(3), 517-551.

Gupta, Nandini and Kathy Yuan. 2005. "On the Growth Effects of Liberalizations," University of Michigan Working Paper.

Haddad, Mona and Ann Harrison. 1993. "Are There Positive Spillovers from Direct Foreign Investment? Evidence from Panel Data for Morocco," Journal of Development Economics, 42, 51-74.

Hall, Robert E. and Charles I. Jones. 1999. "Why Do Some Countries Produce So Much More Output per Worker Than Others?" Quarterly Journal of Economics, 114(1), 83-116.

Harberger, Arnold. 1998. "A Vision of the Growth Process," American Economic Review, 88(1), $1-32$.

Harrison, Ann, Inessa Love, and Margaret McMillan. 2004. "Global Capital Flows and Financing Constraints," Journal of Development Economics, 75(1), 269-301.

Henry, Peter Blair. 2000a. "Stock Market Liberalization, Economic Reform, and Emerging Market Equity Prices," Journal of Finance, 55(2), 529-564.

Henry, Peter Blair. 2000b. "Do Stock Market Liberalizations Cause Investment Booms?" Journal of Financial Economics, 58(1-2), 301-334.

Henry, Peter Blair. 2002. "Is Disinflation Good for the Stock Market?" Journal of 
Finance, 57, 1617-1648.

Henry, Peter Blair. 2003. "Capital Account Liberalization, the Cost of Capital, and Economic Growth,” American Economic Review, 93(2), 91-96.

Henry, Peter Blair and Peter L. Lorentzen. 2003. "Domestic Capital Market Reform and Access to Global Financial Markets: Making Markets Work" in The Future of Domestic Capital Markets in Developing Countries, Robert E. Litan, M. Pomerleano, and V. Sundararajan (eds.), Brookings Press, pp. 170-214.

Himmelberg, Charles P., R. Glenn Hubbard, and Inessa Love. 2002. "Investor Protection, Ownership, and the Cost of Capital," Policy Research Working Paper 2834, Washington: World Bank.

Hubbard, R. Glenn. 1998. “Capital Market Imperfections and Investment,” Journal of Economic Literature, 36, 193-225.

Jensen, Michael C. 1986. "The Agency Costs of Free Cash Flow: Corporate Finance and Takeovers," American Economic Review 76(2), 323-329.

Johnson, Simon and Todd Mitton. 2002. "Cronyism and Capital Controls: Evidence From Malaysia," Journal of Financial Economics, 67, 351-382.

Johnson, Simon, Peter Boone, Alasdair Breach, and Eric Friedman. 2000. "Corporate Governance in the Asian Financial Crisis," Journal of Financial Economics 58(1-2), 141-186.

Kaminsky, Graciela and Sergio Schmukler. 2002. "Short-Run Pain, Long-Run Gain: The Effects of Financial Liberalization” NBER Working Paper 2912

Kaplan, Steven and Luigi Zingales. 1997. "Do Investment-Cash Flow Sensitivities Provide Useful Measures of Financing Constraints?" Quarterly Journal of Economics, 112, 159216.

Kaplan, Steven and Luigi Zingales. 2000. "Investment-Cash Flow Sensitivities Are Not Valid Measures of Financing Constraints," Quarterly Journal of Economics, 115, 707-712.

Karolyi, G. Andrew. 1998. Why Do Companies List Shares Abroad: A Survey of the Evidence and Its Managerial Implications, Financial Markets. Institutions and Instruments 7 , Boston: Blackwell Publishers.

Karolyi, G. Andrew. 2004. "The Role of ADRs in the Development of Emerging Equity Markets," Review of Economics and Statistics, 86(3), 670-690.

Karolyi, G. Andrew and René M. Stulz. 2001. "Are Financial Assets Priced Locally or Globally?" Handbook of the Economics of Finance, forthcoming. 
Kim, E. Han and Vijay Singal. 2000. "Stock Market Openings: Experience of Emerging Economies," Journal of Business, 73, 25-66.

King, Robert and Ross Levine. 1993. "Finance and Growth: Schumpeter Might be Right," Quarterly Journal of Economics, 108 (3), 717-738.

Klein, Michael and G. Olivei. 2000. "Capital Account Liberalization, Financial Depth, and Economic Growth," Tufts University Working Paper.

Kose, Ayhan, Eswar Prasad, Kenneth Rogoff, and Shang-Jin Wei. 2006. "Financial Globalization: A Reappraisal,” NBER Working Paper No. 12484.

Kraay, Aart. 1998. "In Search of the Macroeconomic Effects of Capital Account Liberalization," World Bank Working Paper.

Krueger, Anne O. 1997. "Trade Policy and Economic Development: How We Learn," American Economic Review, 87(1), 1-22.

Krueger, Anne O. 1998. "Why Trade Liberalization is Good for Growth," Economic Journal, $108,1513-1522$.

Krueger, Anne O. 2000. "Conflicting Demands on the International Monetary Fund," American Economic Review, 90(2), 38-42

Laeven, Luc. 2003. "Does Financial Liberalization Reduce Financing Constraints?” Financial Management, Spring, 5-34.

LaPorta, Rafael, Florencio Lopez-de-Silanes, Andrei Shleifer, and Robert Vishny. 1997. "Legal Determinants of External Finance," Journal of Finance, 52, 1131-1150.

LaPorta, Rafael, Florencio Lopez-de-Silanes, Andrei Shleifer, and Robert Vishny. 1998. "Law and Finance," Journal of Political Economy, 106, 1113-1155.

LaPorta, Rafael, Florencio Lopez-de-Silanes, Andrei Shleifer, and Robert Vishny. 2002. "Investor Protection and Corporate Valuation," Journal of Finance 57(3), 1147-1170.

Lessard, Donald R. 1973. "International Portfolio Diversification: A Multivariate Analysis for A Group of Latin American Countries," Journal of Finance, 28(3), 619-633.

Lessard, Donald R. 1994. Commentary on "The Effect of Barriers to Equity Investment in Developing Countries" in The Internationalization of Equity Markets, Jeffrey A. Frankel, (ed.), University of Chicago Press, Chicago and London.

Levine, Ross. 1997. "Financial Development and Growth: Views and Agenda," Journal of Economic Literature, 35(2), 688-726. 
Levine, Ross. 2001. "International Financial Liberalization and Economic Growth," Review of International Economics, 9(4), 688-702.

Levine, Ross and Sergio Schmukler. 2005. Internationalization and the Evolution of Corporate Valuation," NBER Working Paper 11023.

Levine, Ross and Sara Zervos. 1994. "Capital Control Liberalization and Stock Market Development: Data Annex of Country Policy Changes," World Bank, Washington, D.C.

Levine, Ross and Sara Zervos. 1998a. "Stock Markets, Banks, and Economic Growth," American Economic Review, 88, 537-558.

Levine, Ross and Sara Zervos. 1998b. "Capital Control Liberalization and Stock Market Development,” World Development 26(7), 1169-1183.

Lewis, Karen K. 1999. "Trying to Explain Home Bias in Equities and Consumption," Journal of Economic Literature 37(2), 571-608.

Lewis, Karen K. 2000. "Why Do Stocks and Consumption Imply Such Different Gains from International Risk Sharing?” Journal of International Economics, 52, 1-35.

Li, Kan, Randall Morck, Fan Yang, and Bernard Yeung. 2004. "Firm-Specific Variation and Openness in Emerging Markets," Review of Economics and Statistics, Forthcoming.

López-de-Silanes, Florencio. 2002. “The Politics of Legal Reform,” Economia, 2(2), 91-152.

Love, Inessa. 2003. "Financial Development and Financing Constraints: International Evidence From the Structural Investment Model,” Review of Financial Studies, 16(3), 765-791.

Lucas, Robert E. Jr. 1990. "Why Doesn't Capital Flow from Rich to Poor Countries?" American Economic Review, 80(2), 92-96.

Mankiw, Gregory N. 1995. "The Growth of Nations," Brookings Papers on Economic Activity, $1,275-326$.

Martell, Rodolfo and René M. Stulz. 2003. "Equity Market Liberalizations as Country IPOs," American Economic Review, 93(2), 97-101.

Mathieson, Donald J. and Liliana Rojas-Suárez. 1993. "Liberalization of the Capital Account: Experiences and Issues,” IMF Occasional Paper Number 103, Washington, D.C.: International Monetary Fund.

McKinlay, A. Craig. 1997. "Event Studies in Economics and Finance," Journal of Economic Literature 35(1), 13-39.

McKinnon, Ronald I. 1973. Money and Capital in Economic Development, Washington, D.C., 
Brookings Institution.

McKinnon, Ronald I. 1991. The Order of Economic Liberalization, Johns Hopkins University Press, Baltimore.

Megginson, William. 2001. "From State to Market: A Survey of Empirical Studies on Privatization," Journal of Economic Literature, 39, 321-389.

Mishkin, Frederic S. 1996. "Understanding Financial Crises: A Developing Country Perspective" in Annual Bank Conference on Development Economics, Michael Bruno and Boris Pleskovic, (eds.), Washington, D.C.: World Bank, 29-62.

Mishkin, Frederic S. 2000. "Financial Market Reform" in Economic Policy Reform: The Second Stage, Anne O. Krueger (ed.), University of Chicago Press.

Mishkin, Frederic S. 2005. “Is Financial Globalization Beneficial?” Journal of Money Credit and Banking, forthcoming.

Mitton, Todd. 2006. "Stock Market Liberalization and Operating Peformances at the Firm Level," Journal of Financial Economics, forthcoming.

Morck, Randall, David A. Strangeland, and Bernard Yeung. 2000. "Inherited Wealth, Corporate Control, and Economic Growth: The Canadian Disease" in Concentrated Corporate Ownership, R. Morck, (ed.), NBER Conference Volume, University of Chicago Press.

Morck, Randall, Bernard Yeung, and Wayne Yu. 2000. “The Information Content of Stock Markets: Why Do Emerging Markets Have Synchronous Stock Price Movements?" Journal of Financial Economics, 58(1-2), 215-260.

Obstfeld, Maurice. 1994. "Risk-Taking, Global Diversification and Growth," American Economic Review, 84(5), 1310-1329.

Obstfeld, Maurice. 1998. “The Global Capital Market: Benefactor or Menace?” Journal of Economic Perspectives, 12(4), 9-30.

Obstfeld, Maurice and Kenneth Rogoff. 1996. Foundations of International Macroeconomics. MIT Press, Cambridge, MA.

Park, Keith, and Antoine W. Van Agtmael. 1993. The World's Emerging Stock Markets: Structure, Development, Regulations and Opportunities, Chicago: Probus Publishing Company.

Patro, D. K. and J. K. Wald. 2005. "Firm Characteristics and the Impact of Emerging Market Liberalizations," Journal of Banking and Finance, 29(7), 1671-1695.

Pérez González, Francisco. 2005. “The Impact of Acquiring Control on Productivity,” Working Paper, Columbia Business School. 
Portes, Richard and Héléne Rey. 2005. The Determinants of Cross-Border Equity Flows," Journal of International Economics, 65(2), 269-296.

Prasad, Eswar, Kenneth Rogoff, Shang-Jin Wei, and Ayhan Kose. 2003. "Effects of Financial Globalization on Developing Countries; Some New Evidence," IMF Occasional Paper No. 220.

Price, Margaret M. 1994. Emerging Stock Markets, New York: McGraw Hill, Inc.

Quinn, Dennis. 1997. "The Correlates of Change in International Financial Regulation," American Political Science Review, 91(3), 531-551.

Radelet, Steven and Jeffrey Sachs. 1998. "The East Asian Financial Crisis: Diagnosis, Remedies, Prospects," Brookings Papers on Economic Activity, 1, 1-91.

Rajan, Raghuram. 2000. “NBER Corporate Finance Program Report,” NBER Website http://www.nber.org/programs/cf/cf.html.

Rajan, Raghuram and Luigi Zingales. 1998. "Financial Development and Growth," American Economic Review, 88(3), 559-586.

Rajan, Raghuram and Luigi Zingales. 2003. "The Great Reversals: The Politics of Financial Development in the $20^{\text {th }}$ Century," Journal of Financial Economics, 59, 5-50.

Reisen, Helmut and Bernard Fischer. 1993. "Financial Opening: Policy Issues and Experiences in Developing Countries," Paris: OECD Development Center.

Rodrik, Dani. 1998. “Who Needs Capital Account Convertibility?” Princeton Essays in International Finance 207, 55-65.

Rodrik, Dani and Andres Velasco. 2000. "Short-Term Capital Flows" Annual World Bank Conference on Development Economics 1999, pp. 59-90. Washington: World Bank.

Rogoff, Kenneth. 1999. "International Institutions for Reducing Global Financial Instability,” Journal of Economic Perspectives, 13(4), 21-42.

Sachs, Jeffrey and Andrew Warner. 1995. "Economic Reform and the Process of Global Integration," Brookings Papers on Economic Activity, 1, 1-95.

Shaw, Edward S. 1973. Financial Deepening in Economic Development, New York: Oxford University Press.

Shleifer, Andrei and Robert Vishny. 1997. "A Survey of Corporate Governance," Journal of Finance, 52, 737-783.

Shleifer, Andrei and Daniel Wolfenzon. 2002. "Investor Protection and Equity 
Markets," Journal of Financial Economics, 66, 3-57.

Shin, Inseok and Changyun Park. 2006. "Stock Market Opening and the Cost of Capital: The Case of Korea," forthcoming in International Financial Issues Around the Pacific Rim, East Asia Seminar on Economics,17, Takatoshi Ito and Andrew Rose (eds.), University of Chicago Press.

Solow, Robert M. 1956. "A Contribution to the Theory of Economic Growth," Quarterly Journal of Economics, 70, 65-94.

Solow, Robert M. 2000. Growth Theory: An Exposition, Oxford University Press

Solow, Robert M. 2001. “Applying Growth Theory Across Countries," World Bank Economic Review, 15(2), 283-288.

Stein, Jeremy C. 2003. "Agency, Information and Corporate Investment" in the Handbook of the Economics of Finance, Constantinides, Harris and Stulz (eds.), forthcoming.

Stiglitz, Joseph. 1999. "Reforming the Global Economic Architecture: Lessons From Recent Crises," Journal of Finance, 54(4), 1508-1521.

Stiglitz, Joseph. 2000. "Capital Market Liberalization, Economic Growth, and Instability,” World Development, June, 28(6), 1075-1086.

Stiglitz, Joseph. 2002. Globalization and Its Discontents, W.W. Norton.

Stulz, René M. 1999a. "International Portfolio Flows and Security Markets," in International Capital Flows, M. Feldstein (ed.), University of Chicago Press, 257-293.

Stulz, René M. 1999b. "Globalization of Equity Markets and the Cost of Capital," New York Stock Exchange Working Paper 99-2.

Stulz, René M. 1999c. "Globalization, Corporate Finance, and the Cost of Capital," Journal of Applied Corporate Finance 12(3): 8-25.

Stulz, René M. 2005. “The Limits of Financial Globalization," Journal of Finance, 60(4), 15951638.

Summers, Lawrence H. 1994. "A Changing Course Toward Privatization” in GA. Galal and M. Shirley eds.: Does Privatization Deliver? Washington, D.C.: The World Bank.

Summers, Lawrence. 2000. "International Financial Crises: Causes, Prevention, and Cures," American Economic Review, 90(2), 1-16.

Suttle, Philip. 2003. "Financial Flows to Developing Countries: Recent Trends and Near-Term Prospects," Global Development Finance: Striving for Stability in Development Finance, Washington: World Bank. 
Tesar, Linda L. and Ingrid M. Werner. 1998. "The Internationalization of Securities Markets Since the 1987 Crash" in Brookings Wharton Papers on Financial Services, Robert E. Litan and Anthony M. Santomero (eds.), Washington, DC: Brookings Institution Press.

Tobin, James and William C. Brainard. 1977. "Asset Markets and the Cost of Capital" in Balassa, B. and Nelson, R. (Eds.), Economic Progress, Private Values, and Public Policy. North Holland, Amsterdam, pp. 235-62.

Van Wincoop, Eric. 1994. "Welfare Gains from International Risk Sharing," Journal of Monetary Economics, 34,175-200.

Van Wincoop, Eric. 1999. "How Big Are Potential Welfare Gains from International Risk Sharing?" Journal of International Economics, 47(1), 109-135.

Wacziarg, Romain and Karen Welch. 2003. "Trade Liberalization and Growth: New Evidence" NBER Working Paper No. 10152

Williamson, John. 1997. "Prospects for Avoiding Crises with Liberalized Capital Flows," Estudios de Economía, 24(2), 287-295.

Wilson, Ian M. 1992. The Wilson Directory of Emerging Market Funds, Saskatoon: Wilson Emerging Market Funds Research.

Wurgler, Jeffrey. 2000. "Financial Markets and the Allocation of Capital," Journal of Financial Economics 58(1), 187-214. 
Table 1. Dates of Stock Market Liberalizations and Major Economic Reforms

\begin{tabular}{|c|c|c|c|c|c|c|}
\hline Country & $\begin{array}{l}\text { Year of } \\
\text { Liberalization }\end{array}$ & $\begin{array}{l}\text { Means of } \\
\text { Liberalization }\end{array}$ & $\begin{array}{l}\text { Stabilization } \\
\text { Program }\end{array}$ & $\begin{array}{l}\text { Trade } \\
\text { Liberalization }\end{array}$ & Privatization & $\begin{array}{l}\text { Brady Plan Debt } \\
\text { Relief }\end{array}$ \\
\hline Argentina & November 1989 & Policy Decree & November 1989 & April 1991 & February 1988 & April 1992 \\
\hline Brazil & March 1988 & Country Fund & January 1989 & April 1990 & July 1990 & August 1992 \\
\hline Chile & May 1987 & Country Fund & August 1985 & 1976 & 1988 & NA \\
\hline Colombia & December 1991 & Policy Decree & NA & 1986 & 1991 & NA \\
\hline India & June 1986 & Country Fund & November 1981 & 1994 & 1991 & NA \\
\hline Indonesia & September 1989 & Policy Decree & May 1973 & 1970 & 1991 & NA \\
\hline Jordan & December 1995 & Policy Decree & May 1994 & 1965 & January 1995 & June 1993 \\
\hline Malaysia & May 1987 & Country Fund & NA & 1963 & 1988 & NA \\
\hline Mexico & May 1989 & Policy Decree & May 1989 & July 1986 & November 1988 & September 1989 \\
\hline Nigeria & August 1995 & Policy Decree & January 1991 & NA & July 1988 & March 1991 \\
\hline Pakistan & February 1991 & Policy Decree & September 1993 & 2001 & 1990 & NA \\
\hline Philippines & May 1986 & Country Fund & October 1986 & November 1988 & June 1988 & August 1989 \\
\hline South Korea & June 1987 & Country Fund & July 1985 & 1968 & NA & NA \\
\hline Taiwan & May 1986 & Country Fund & & 1963 & NA & NA \\
\hline Thailand & September 1987 & Country Fund & June 1985 & Always Open & 1988 & NA \\
\hline Turkey & August 1989 & Policy Decree & July 1994 & 1989 & 1988 & NA \\
\hline Venezuela & January 1990 & Policy Decree & June 1989 & May $1989 * *$ & April 1991 & June 1990 \\
\hline Zimbabwe & June 1993 & Policy Decree & September 1992 & NA & 1994 & NA \\
\hline
\end{tabular}


Table 2. The Economic Infrastructure of Emerging Markets Is Weaker Than That of Developed Countries.

\begin{tabular}{|c|c|c|c|c|}
\hline & $\begin{array}{l}\text { Hall and Jones (1999): } \\
\text { Social Infrastructure Index }\end{array}$ & $\begin{array}{l}\text { Heritage House: Index } \\
\text { of Economic Freedom }\end{array}$ & $\begin{array}{l}\text { World Bank: Ease of } \\
\text { Doing Business Index }\end{array}$ & $\begin{array}{l}\text { World Economic Forum: } \\
\text { Global Competitiveness Index }\end{array}$ \\
\hline Argentina & 77 & 23 & 101 & 69 \\
\hline Brazil & 68 & 87 & 121 & 66 \\
\hline Chile & 43 & 15 & 28 & 27 \\
\hline Colombia & 79 & 73 & 79 & 65 \\
\hline India & 87 & 126 & 134 & 43 \\
\hline Indonesia & 45 & 76 & 135 & 50 \\
\hline Jordan & 34 & 58 & 78 & 52 \\
\hline Malaysia & 22 & 42 & 25 & 26 \\
\hline Mexico & 64 & 91 & 43 & 58 \\
\hline Nigeria & 116 & 97 & 108 & 101 \\
\hline Pakistan & 113 & 107 & 74 & 91 \\
\hline Philippines & 90 & 69 & 126 & 71 \\
\hline South Korea & 33 & 33 & 23 & 24 \\
\hline Taiwan & 28 & 16 & 47 & 13 \\
\hline Thailand & 20 & 38 & 18 & 35 \\
\hline Turkey & 71 & 49 & 91 & 59 \\
\hline Venezuela & 53 & 99 & 104 & 88 \\
\hline Zimbabwe & 94 & 122 & 153 & 119 \\
\hline Average Emerging Market & 63 & 68 & 83 & 59 \\
\hline $\begin{array}{l}\text { Average Developed } \\
\text { Country }\end{array}$ & 14 & 14 & 23 & 15 \\
\hline
\end{tabular}


Table 3. Investor Protection in Emerging Markets Is Weaker Than in Developed Countries.

\begin{tabular}{|c|c|c|c|c|c|}
\hline & Rule of Law & Judicial Efficiency & Contract Repudiation & Expropriation Risk & Accounting Standards \\
\hline Argentina & 5.4 & 6.0 & 4.9 & 5.9 & 4.5 \\
\hline Brazil & 6.3 & 5.8 & 6.3 & 7.6 & 5.4 \\
\hline Chile & 7.0 & 7.3 & 6.8 & 7.5 & 5.2 \\
\hline Colombia & 2.1 & 7.3 & 7.0 & 7.0 & 5 \\
\hline India & 4.2 & 8.0 & 6.1 & 7.8 & 5.7 \\
\hline Indonesia & 4.0 & 2.5 & 6.1 & 7.2 & NA \\
\hline Jordan & 4.4 & 8.7 & 4.9 & 6.1 & NA \\
\hline Malaysia & 6.8 & 9.0 & 7.4 & 8.0 & 7.6 \\
\hline Mexico & 5.4 & 6.0 & 6.6 & 7.3 & 6 \\
\hline Nigeria & 2.7 & 7.3 & 4.4 & 5.3 & 5.9 \\
\hline Pakistan & 3.0 & 5.0 & 4.9 & 5.6 & NA \\
\hline Philippines & 2.7 & 4.8 & 4.8 & 5.2 & 6.5 \\
\hline South Korea & 5.4 & 6.0 & 8.6 & 8.3 & 6.2 \\
\hline Taiwan & NA & NA & NA & NA & NA \\
\hline Thailand & 6.3 & 3.3 & 7.6 & 7.4 & 6.4 \\
\hline Turkey & 5.2 & 4.0 & 6.0 & 7.0 & 5.1 \\
\hline Venezuela & 6.4 & 6.5 & 6.3 & 6.9 & 4 \\
\hline Zimbabwe & 3.7 & 7.5 & 5.0 & 5.6 & NA \\
\hline Emerging Market Mean & 4.8 & 6.2 & 6.1 & 6.8 & 5.7 \\
\hline $\begin{array}{l}\text { Developed Country } \\
\text { Mean }\end{array}$ & 9.1 & 9.2 & 9.2 & 9.5 & 6.4 \\
\hline
\end{tabular}

Source: Lopez-de-Silanes (2002) 
Table 4 Composition of Capital Inflows to Developing Countries 1970-95

\begin{tabular}{|c|c|c|c|c|c|c|c|c|c|c|}
\hline & \multicolumn{2}{|c|}{ Average 1970-74 } & \multicolumn{2}{|c|}{ Average 1975-79 } & \multicolumn{2}{|c|}{ Average 1980-84 } & \multicolumn{2}{|c|}{ Average 1985-89 } & \multicolumn{2}{|c|}{ Average 1990-95 } \\
\hline & $\begin{array}{l}\text { Millions } \\
\text { of dollars }\end{array}$ & $\begin{array}{c}\text { Percent of } \\
\text { total }\end{array}$ & $\begin{array}{l}\text { Millions } \\
\text { of dollars }\end{array}$ & $\begin{array}{c}\text { Percent of } \\
\text { total }\end{array}$ & $\begin{array}{l}\text { Millions } \\
\text { of dollars }\end{array}$ & $\begin{array}{c}\text { Percent of } \\
\text { total }\end{array}$ & $\begin{array}{l}\text { Millions } \\
\text { of dollars }\end{array}$ & $\begin{array}{c}\text { Percent of } \\
\text { total }\end{array}$ & $\begin{array}{l}\text { Millions } \\
\text { of dollars }\end{array}$ & $\begin{array}{c}\text { Percent of } \\
\text { total }\end{array}$ \\
\hline $\begin{array}{l}\text { Net Resource } \\
\text { Flows }\end{array}$ & 12529.1 & & 32836.8 & & 51604.7 & & 32726.2 & & 90184.1 & \\
\hline $\begin{array}{l}\text { Net Flows on Debt } \\
\text { (PPG+PNG) }\end{array}$ & 10121.3 & 80.8 & 27151.3 & 82.7 & 42374.6 & 82.1 & 20563.4 & 62.8 & 45316.2 & 50.2 \\
\hline $\begin{array}{l}\text { Public and Publicly } \\
\text { Guaranteed debt (PPG) }\end{array}$ & 5628.0 & 44.9 & 18014.0 & 54.9 & 28383.4 & 55.0 & 14844.5 & 45.4 & 12820.5 & 14.2 \\
\hline $\begin{array}{l}\text { Private Nonguaranteed } \\
\text { debt (PNG) }\end{array}$ & 4493.4 & 35.9 & 9137.3 & 27.8 & 13991.2 & 27.1 & 5718.9 & 17.5 & 32495.8 & 36.0 \\
\hline $\begin{array}{l}\text { Foreign Direct } \\
\text { Investment }\end{array}$ & 1798.6 & 14.4 & 4247.2 & 12.9 & 6871.7 & 13.3 & 9006.5 & 27.5 & 24993.8 & 27.7 \\
\hline Portfolio Equity & 0.0 & 0.0 & 0.0 & 0.0 & 27.0 & 0.1 & 762.2 & 2.3 & 16855.0 & 18.7 \\
\hline Grants & 609.2 & 4.9 & 1438.3 & 4.4 & 2331.3 & 4.5 & 2394.2 & 7.3 & 3019.0 & 3.3 \\
\hline
\end{tabular}




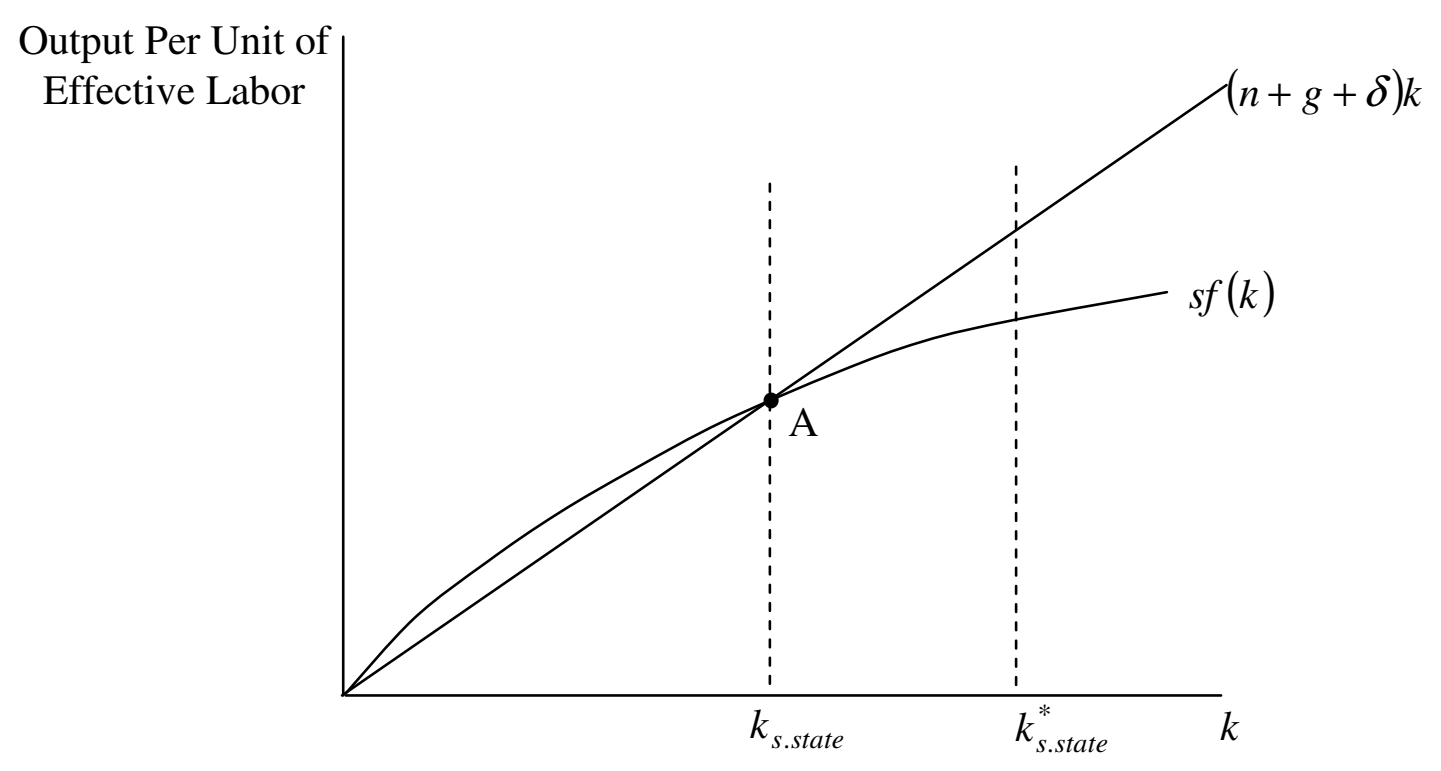

Figure 1: Capital Account Liberalization in the Neoclassical Growth Model 

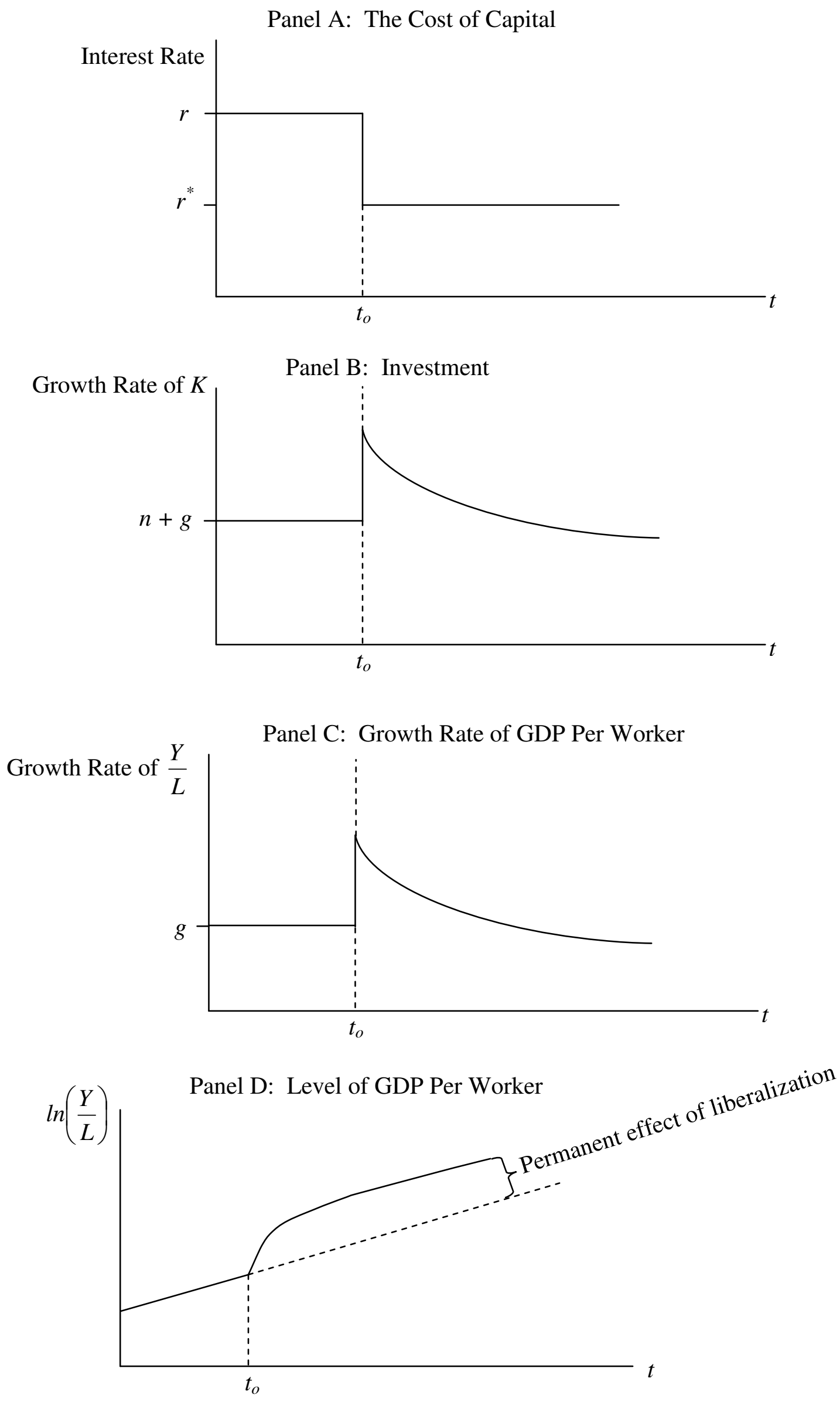

Figure 2: The Impact of Liberalization on the Cost of Capital, Investment, and Growth. 


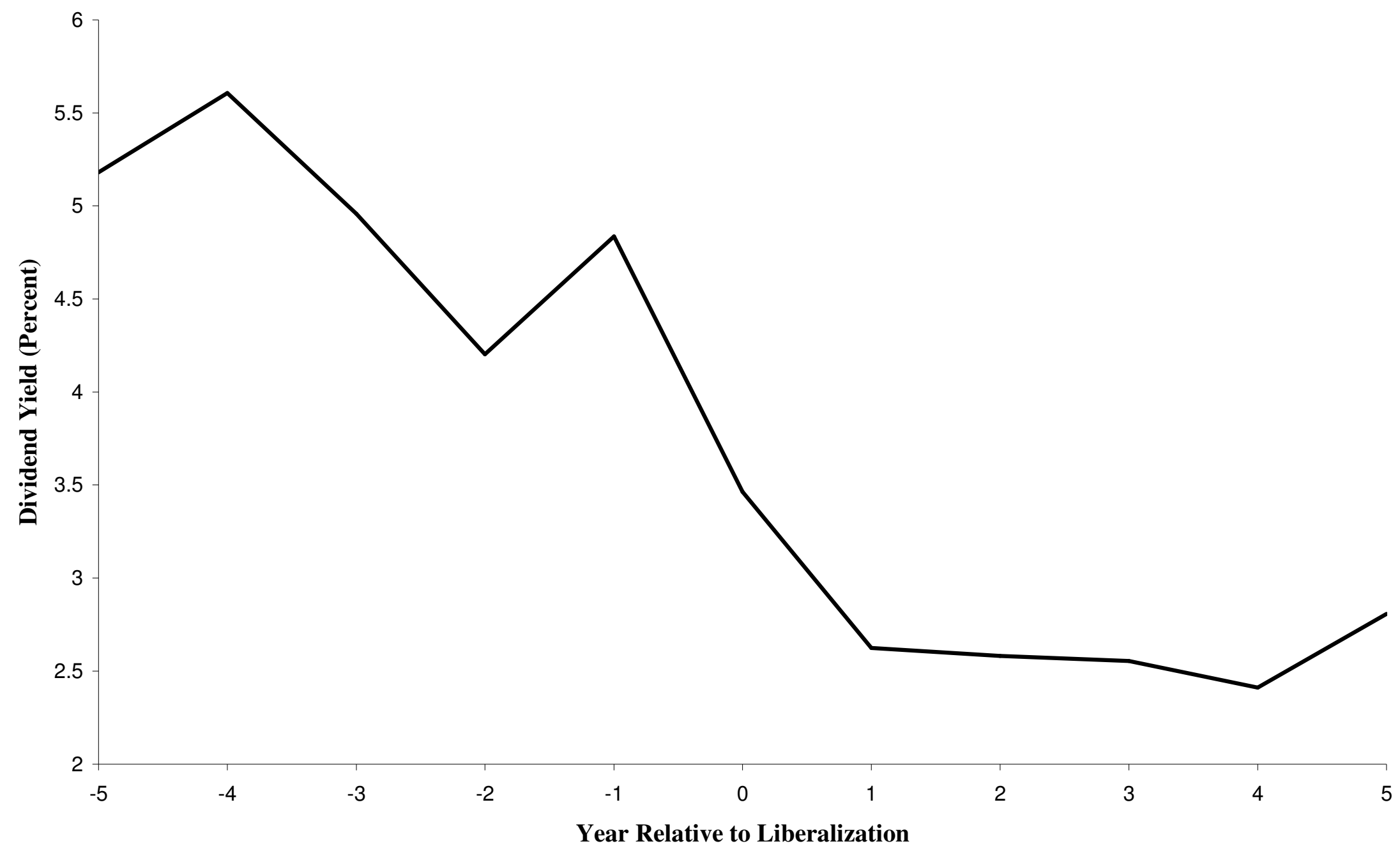

Figure 3. The Cost of Capital Capital Falls When Countries Liberalize the Capital Account. 


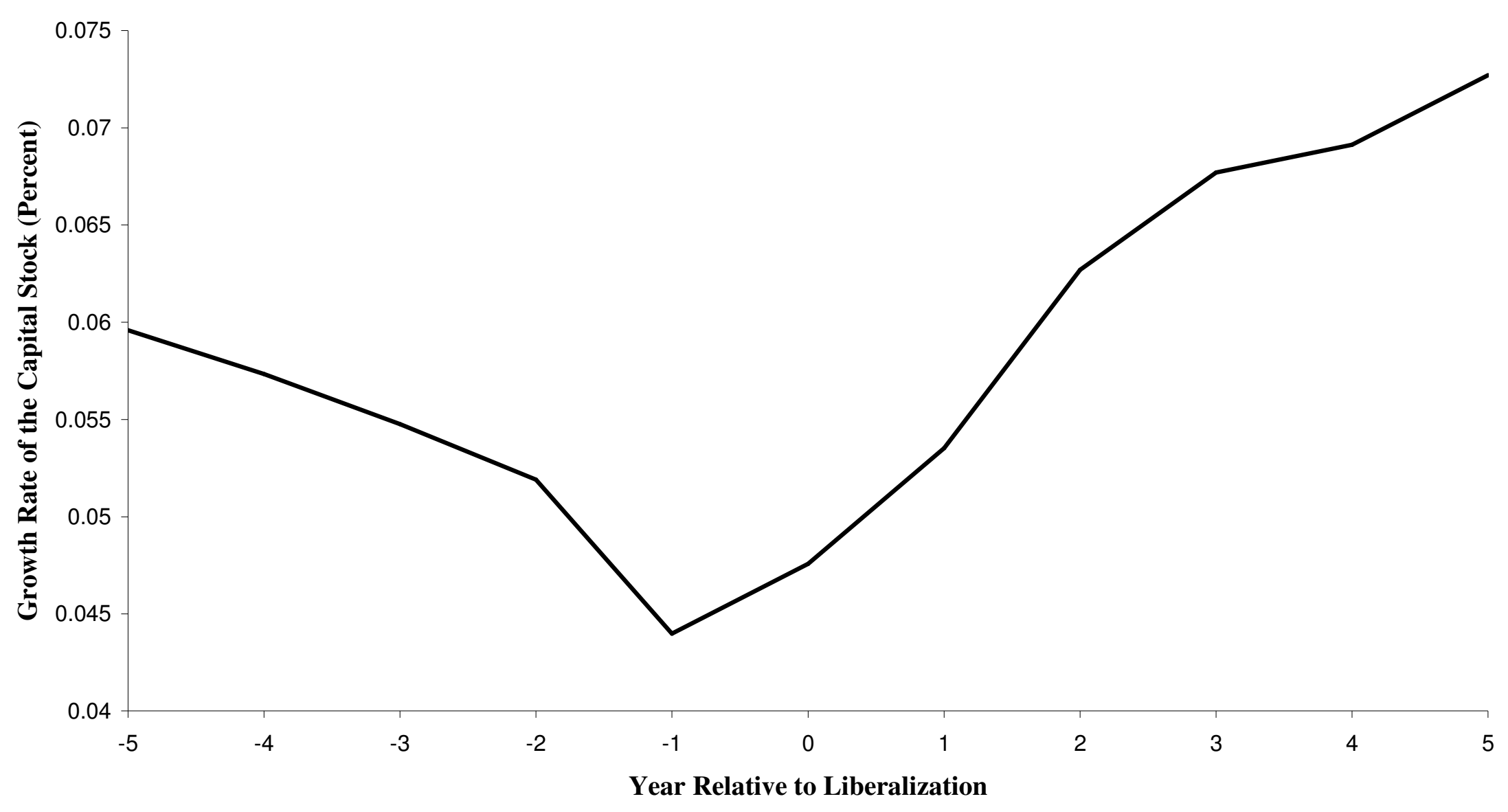

Figure 4. Investment Booms When Countries Liberalize the Capital Account . 


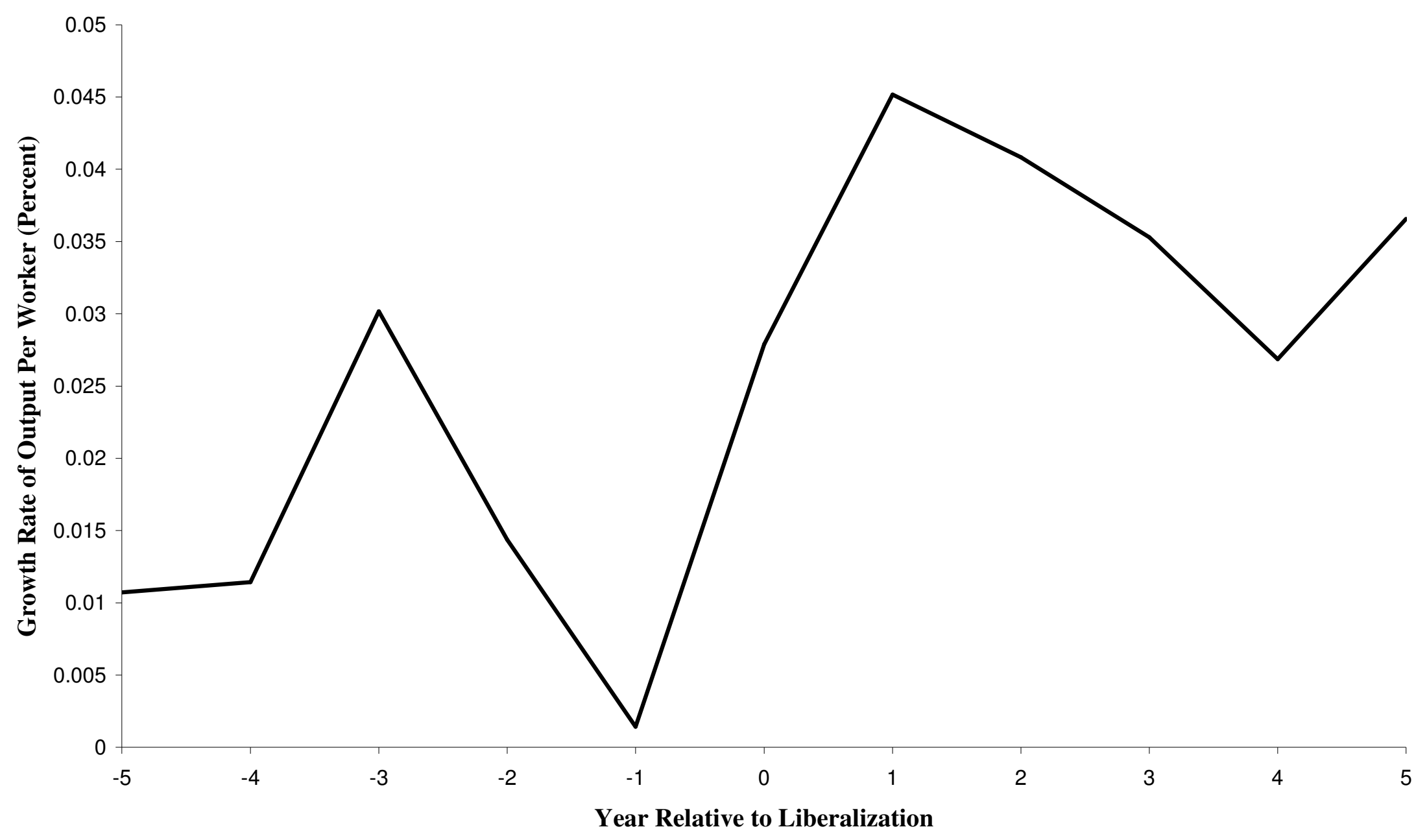

Figure 5. The Growth Rate of Output Per Worker Increases When Countries Liberalize. 